\title{
Constraining the formation of authigenic carbonates in a seepage-affected cold-water coral mound by lipid biomarkers
}

\author{
Eline Juliette Feenstra ${ }^{1}$ (1) | Daniel Birgel ${ }^{2}$ | Katrin Heindel ${ }^{3}$ | Laura M. Wehrmann ${ }^{4}$ | \\ David Jaramillo-Vogel $^{1}$ | Bernard Grobéty ${ }^{1}$ | Norbert Frank ${ }^{5}$ | Leanne G. Hancock ${ }^{6}$ | \\ David Van Rooij $^{7}$ | Jörn Peckmann ${ }^{2}$ (D) | Anneleen Foubert ${ }^{1}$
}

\footnotetext{
${ }^{1}$ Department of Geosciences, University of Fribourg, Fribourg, Switzerland

${ }^{2}$ Center for Earth System Research and Sustainability, University of Hamburg, Hamburg, Germany

${ }^{3}$ Department for Geodynamics and Sedimentology, University of Vienna, Vienna, Austria

${ }^{4}$ School of Marine and Atmospheric Sciences, SUNY Stony Brook, Stony Brook, NY, USA

${ }^{5}$ Institute of Environmental Physics, University of Heidelberg, Heidelberg, Germany

${ }^{6}$ Department of Earth and Environmental Sciences, Michigan State University, East Lansing, MI, USA

${ }^{7}$ Renard Centre of Marine Geology, Department of Geology, Ghent University, Ghent, Belgium

Correspondence

Eline Juliette Feenstra, Department of Geosciences, University of Fribourg, Fribourg, Switzerland.

Email: eline.feenstra@unifr.ch

Funding information

Swiss National Science Foundation, Grant/ Award Number: 4D-Diagenesis@Mound SNF project number 200021_149247
}

\begin{abstract}
Cold-water coral (CWC) mounds are build-ups comprised of coral-dominated intervals alternating with a mixed carbonate-siliciclastic matrix. At some locations, CWC mounds are influenced by methane seepage, but the impact of methane on CWC mounds is poorly understood. To constrain the potential impact of methane on CWC mound growth, lipid biomarker investigations were combined with mineralogical and petrographic analyses to investigate the anaerobic oxidation of methane (AOM) and authigenic carbonate formation in sediment from a seep-affected CWC mound in the Gulf of Cadiz. The occurrence of AOM was confirmed by characteristic lipids found within a semi-lithified zone (SLZ) consisting of authigenic aragonite, highmagnesium calcite and calcium-excess dolomite. The formation of high-Mg calcite is attributed to AOM, acting as a lithifying agent. Aragonite is only a minor phase. Caexcess dolomite in the SLZ and upper parts may be formed by organoclastic sulphate reduction, favouring precipitation by increased alkalinity. The AOM biomarkers in the SLZ include isoprenoid-based archaeal membrane lipids, such as abundant glycerol dibiphytanyl glycerol tetraethers (GDGTs) dominated by GDGT-2. The $\delta^{13} \mathrm{C}$ values of GDGT-2, measured as ether-cleaved monocyclic biphytanes, are as low as $-100 \%$ o versus $\mathrm{V}$-PDB. Further, bacterial dialkyl glycerol diethers with two anteiso- $\mathrm{C}_{15}$ alkyl chains and $\delta^{13} \mathrm{C}$ values of $-81 \%$ are interpreted as biomarkers of sulphate-reducing bacteria. The lipid biomarker signatures and mineralogical patterns suggest that anaerobic methane-oxidizing archaea of the ANME-1 group thrived in the subsurface at times of slow and diffusive methane seepage. Petrographic analyses revealed that the SLZ was exhumed at some point (e.g. signs of bioerosion of the semi-lithified sediment), providing a hard substrate for CWC larval settlement. In addition, this work reveals that AOM-induced semi-lithification likely played a role in mound stabilization. Lipid biomarker analysis proves to be a powerful tool to disentangle early diagenetic processes induced by microbial metabolisms.
\end{abstract}

\section{KEYWORDS}

authigenic carbonates, cold-water coral mounds, cold-water corals, Gulf of Cadiz, lipid biomarkers, sulphate methane transition zone 


\section{1 | INTRODUCTION}

Cold-water coral (CWC) ecosystems occur worldwide on continental margins, most commonly below the photic zone (Roberts, Wheeler, \& Freiwald, 2006). The CWC species predominantly consist of the framework-building azooxanthellate, scleractinian corals Lophelia pertusa (recently renamed as Desmophyllum pertusum (Addamo et al., 2016)) and Madrepora oculata (Freiwald, 2002). Some CWC ecosystems form large carbonate build-ups, with conical mounds or ridgelike morphologies. These mounds consist of coral-dominated intervals alternating with a mixed carbonate-siliciclastic matrix. They can be found in the Porcupine Seabight northwest of Ireland (De Mol et al., 2002; Huvenne, De Mol, \& Henriet, 2003), the Gulf of Cadiz off the Moroccan coast (Foubert et al., 2008; Van Rooij et al., 2011; Wienberg et al., 2009, 2010) and the Alboran Sea in the western Mediterranean (Fink, Wienberg, De Pol-Holz, Wintersteller, \& Hebbeln, 2013; Stalder et al., 2015, 2018). These build-ups range from several tens to hundreds of metres in height, and their bases can reach a diameter of several kilometres (De Mol et al., 2002; Dorschel, Hebbeln, Rüggeberg, Dullo, \& Freiwald, 2005; Huvenne et al., 2003; Van Weering, de Haas, de Stigter, Lykke-Andersen, \& Kouvaev, 2003; Wheeler et al., 2007).

The occurrence and distribution of CWCs is controlled by environmental conditions. Their distribution is confined to specific hydrodynamic properties, where temperature, salinity and dissolved oxygen concentration are usually within $4-14^{\circ} \mathrm{C}, 31.7-38.8 \mathrm{psu}$ and 2.6-7.2 ml/L, respectively (Davies, Wisshak, Orr, \& Murray Roberts, 2008; Dullo, Flögel, \& Rüggeberg, 2008; Freiwald, Fossa, Grehan, Koslow, \& Roberts, 2004; Roberts et al., 2006; Rüggeberg et al., 2008). Additionally, CWC reefs are associated with the presence of relatively strong bottom currents, which supply sufficient food, protect against burial (Freiwald, 2002; Hebbeln, Van Rooij, \& Wienberg, 2016; Roberts, Wheeler, Freiwald, \& Cairns, 2009) and expose suitable substrate for larval settlement (Rincón-Tomás et al., 2019; Rüggeberg \& Foubert, 2019). Therefore, records of CWC mounds have proven valuable archives of palaeoceanographic and palaeoclimatic conditions of the meso- and bathypelagic zone (Frank et al., 2011; Thierens et al., 2010, 2013).

Cold-water coral growth has also been linked with methane seepage based on the frequent observation of CWCs on top of faults (which potentially act as conduits for seepage) and mud volcanoes (Foubert et al., 2008; Henriet et al., 1998; Hovland, 1990; Hovland, Jensen, \& Indreiten, 2012; Hovland, Mortensen, Brattegard, Strass, \& Rokengen, 1998; Hovland \& Thomsen, 1997; Margreth et al., 2011; Rincón-Tomás et al., 2019). Yet, the role of methane seepage in CWC mound formation is not fully understood. Initially, it was thought that the corals might also feed on the nutrients or chemosynthetic fauna of seeps, but this has not yet been demonstrated. More recent studies posit that methane-derived authigenic carbonate represents a suitable substrate for CWC larval settlement (Bohrmann, Greinert, Suess, \& Torres, 1998; Greinert, Bohrmann, \& Suess, 2001; Magalhães et al., 2012; Michaelis et al., 2002; Peckmann et al., 2001; Rincón-Tomás et al., 2019; Rüggeberg \& Foubert, 2019).
To gain further understanding of the role of methane seepage in CWC mounds, a 6-m gravity core from the 15-m high CWCbearing Alpha Mound on the Pen Duick Escarpment (PDE) was retrieved. Alpha Mound is situated in the active El Arraiche mud volcano field characterized by methane seepage and fluid venting (Van Rensbergen, Depreiter, Pannemans, Moerkerke, 2005). Mud volcano activity is linked to continued overpressure at depth by either in situ oil and gas generation or by focused flow along the basal detachment of the accretionary wedge and gas accumulation in the area (Van Rensbergen et al., 2005). The methane escaping from the sediments in the El Arraiche field has a mixed but dominantly deep, thermogenic origin (Hensen et al., 2007; Maignien et al., 2011; Stadnitskaia, Ivanov, Blinova, Kreulen, \& van Weering, 2006). Today, methane gas has been measured in the pore waters of Alpha Mound, but no active bubbling of gas has been observed at its surface (Van Rooij et al., 2011; Wehrmann et al., 2011). Previous studies have used Alpha Mound as a model for investigating the impact of methane seepage on CWC mound sediments (Maignien et al., 2011; Pirlet et al., 2012; Templer, Wehrmann, Zhang, Vasconcelos, \& McKenzie, 2011; Wehrmann et al., 2011). Various proxies (e.g. $\delta^{34} \mathrm{~S}_{\mathrm{CRS}}, \delta^{13} \mathrm{C}_{\text {carbonate }}$, degree of pyritization, pore water analyses, taxonomic and functional gene markers) suggest the presence of a shallow and fluctuating sulphate-methane transition zone (SMTZ) impacting the CWC mound sediments. However, it has proven to be difficult to separate AOM from various other biogeochemical and diagenetic processes occurring at Alpha Mound due to superimposed geochemical signatures. This circumstance has made it challenging to constrain the role of methane seepage in CWC mounds.

This study applies lipid biomarker analyses to Alpha Mound sediments to distinguish AOM from other microbial processes for the first time. Lipid biomarkers have been successfully used to identify carbonates associated with AOM in other localities (Birgel et al., 2006; Blumenberg, Seifert, Reitner, Pape, \& Michaelis, 2004; Chevalier et al., 2011; Elvert, Suess, Greinert, \& Whiticar, 2000; Elvert, Suess, \& Whiticar, 1999; Michaelis et al., 2002; Pancost, Bouloubassi, Aloisi, Sinninghe Damsté, \& Shipboard Scientific Party, 2001; Pape et al., 2005; Peckmann et al., 1999; Stadnitskaia et al., 2008; Thiel et al., 1999, 2001). AOM and seep carbonates in modern environments are typically associated with the archaeal, ${ }^{13} \mathrm{C}$-depleted isoprenoidal diphytanyl glycerol diethers sn2-hydroxyarchaeol and archaeol, specific distributions of (cyclic) isoprenoidal glycerol dibiphytanyl tetraethers (GDGTs), and the isoprenoid hydrocarbons crocetane and pentamethylicosane (PMI; Birgel et al., 2006; Blumenberg et al., 2004; Chevalier et al., 2011; Elvert, Suess, Greinert, \& Whiticar, 2000; Elvert et al., 1999; Michaelis et al., 2002; Pancost, Bouloubassi, et al., 2001; Pape et al., 2005; Peckmann, Birgel, \& Kiel, 2009; Stadnitskaia et al., 2008; Thiel et al., 1999, 2001). The extremely low $\delta^{13} \mathrm{C}$ values of these biomarkers (as low as $-130 \%$ 。 vs. V-PDB; Elvert et al., 2000) confirm that methane is the source of carbon in these compounds. To constrain the potential impact of methane-derived authigenic carbonate formation on Alpha Mound and CWC mound formation in general, lipid biomarker measurements have been studied together with petrographic and mineralogical analyses. 


\section{2 | STUDY SITE}

\section{1 | Geology and geomorphology}

The geological history of the Gulf of Cadiz (Figure 1a) is complex and includes successive phases of rifting and passive margin formation during the Mesozoic (Dewey, Helman, Knott, Turco, \& Hutton, 1989; Gràcia, Dañobeitia, Vergés, Bartolomé, \& Córdoba, 2003; Maldonado, Somoza, \& Pallarés, 1999; Medialdea et al., 2004, 2009). Large allochthonous wedges were emplaced during the ongoing oblique European-African convergence and the westward motion of the Gibraltar Arc (Betic-Rifean Cordillera) during the Miocene (Maldonado et al., 1999). During the Late Miocene and Early Pliocene, thermal subsidence was followed by extensional collapse of the accretionary wedge (Maldonado et al., 1999).

Large-scale gas generation in the Gulf of Cadiz is thought to originate from the accretionary wedge. The major source of fluids is likely the dehydration of clay minerals during the transformation of smectite to illite within the Mesozoic and Cenozoic shales at a depth of approximately $5 \mathrm{~km}$ below seafloor and within a temperature range of 60$150^{\circ} \mathrm{C}$ (Hensen et al., 2007). Fluid and gas flow is likely related to both along-slope gravity gliding and lateral tectonics of shale/salt units of the accretionary wedge (Somoza et al., 2001). Fluid and gas flow have led to extensive pockmark formation, mud volcanism (Fernández-Puga et al., 2007; Medialdea et al., 2009; Niemann et al., 2006; Pinheiro et al., 2003; Somoza et al., 2001) and the formation of methane-derived authigenic carbonates (Díaz-del-Río, 2003; González et al., 2009; Magalhães et al., 2012; Rejas et al., 2015; Vanneste et al., 2012).

Alpha Mound is situated on top of the Pen Duick Escarpment (PDE) within the El Arraiche mud volcano field (Ivanov, Akhmetzhanov, \& Akhmanov, 2000; Van Rensbergen, Depreiter, Pannemans, \& Henriet, 2005; Van Rensbergen et al., 2005; Figure 1b). The PDE is part of the Renard Ridge and forms a 6-kilometre long, NW-SE oriented, 80-125 m high escarpment with a southwest-facing slope of $8^{\circ}-12^{\circ}$. The Renard and Vernadsky Ridges are created by local uplift and reactivation of diapiric structures. In addition, the field encompasses eight mud volcanoes that most likely root in the CretaceousMiocene accretionary wedge (Van Rensbergen et al., 2005). Al Idrissi is the largest mud volcano with a height of $255 \mathrm{~m}$ and a diameter of $5.4 \mathrm{~km}$ (Figure 1b). Alpha Mound is located on the SE edge of the PDE (Figure 1c). Its estimated width and height are 200 and $15 \mathrm{~m}$, respectively, with an average footprint of $0.27 \mathrm{~km}^{2}$ (Van Rooij et al., 2011).

\section{2 | Oceanography}

The current hydrographic setting of the Gulf of Cadiz is influenced by the exchange of water masses between the Atlantic Ocean and the Mediterranean Sea (Hernández-Molina et al., 2006, 2011; Machín, Pelegrí, Marrero-Díaz, Laiz, \& Ratsimandresy, 2006). In the Gulf of Cadiz, the upper water mass is the North Atlantic Central
Water (NACW; Figure 1a). The lower boundary of the NACW occurs at water depths of $300 \mathrm{~m}$ near the Gibraltar Strait and $600 \mathrm{~m}$ in the Gulf of Cadiz. Below the NACW, between 600 and 1,500 m, two water masses occur, namely the Mediterranean Outflow Water (MOW) in the northern and the Antarctic Intermediate Water (AAIW) in the central part of the Gulf of Cadiz (Figure 1a). Below $1,500 \mathrm{~m}$, North Atlantic Deep Water (NADW) is present (Figure 1a). The hydrographic setting in the southern part of the Gulf of Cadiz is less well known. Pelegrí et al. (2005) reported the presence of MOW at $800 \mathrm{~m}$ along the Moroccan margin, and eddies are known to transport MOW south of the Strait of Gibraltar (Richardson, Bower, \& Zenk, 2000). At the PDE area, no MOW is currently observed but Northern Atlantic Surface Water (NASW; 0-100 m), NACW (100$600 \mathrm{~m}$ ), AAIW (600-1,500) and NADW (below 1,500 m) (Ambar, Serra, Neves, \& Ferreira, 2008; Machín, Hernández-Guerra, \& Pelegrí, 2006).

\section{3 | MATERIALS AND METHODS}

\section{1 | Sample collection and description}

Gravity core MD13-3443G was retrieved from the north-western flank of Alpha Mound $\left(35^{\circ} 17,500^{\prime} \mathrm{N}, 6^{\circ} 47,110^{\prime} \mathrm{W}\right)$ with the research vessel R/V Marion Dufresne (MD) in June 2013 during the EUROFLEETS cruise MD194 Gateway 'The Mediterranean-Atlantic Gateway Code: The Late Pleistocene Carbonate Mound Record'. The core has a total recovery length of $6.29 \mathrm{~m}$ and was taken at a water depth of $528 \mathrm{~m}$. The core covers roughly half of the $\sim 15 \mathrm{~m}$ high Alpha Mound (Van Rooij et al., 2011). Sediment subsamples (100 g each) of core MD13-3443G were taken every $30-50 \mathrm{~cm}$ immediately after opening the core on deck. The samples were then wrapped in aluminium foil and stored in sterile bags at $-20^{\circ} \mathrm{C}$ for lipid extraction. Additional sediments for mineralogical and petrographic analyses were sampled and stored at $4^{\circ} \mathrm{C}$. Sedimentary facies descriptions and logging of the preservation of primary CWC features and morphologies were conducted according to Foubert and Henriet (2009). Preservation of corals is good when the solid theca walls are still intact, and it is possible to see the internal structure of the corals such as the lamination of the different aragonite layers. If this is the case, the aragonite skeletons did not undergo extensive dissolution.

\subsection{X-ray diffractometry}

Sediment (other than bioclasts $>2 \mathrm{~mm}$ ) samples were taken every $10 \mathrm{~cm}$ for mineralogical analyses, except in several semi-lithified intervals where sample frequency was increased to $2 \mathrm{~cm}$. Mineralogical content was determined using powder $x$-ray diffractometry (XRD). All fractions were characterized by a powder XRD Rigaku Ultima IV equipped with a D-Tex position sensitive detector. After drying 


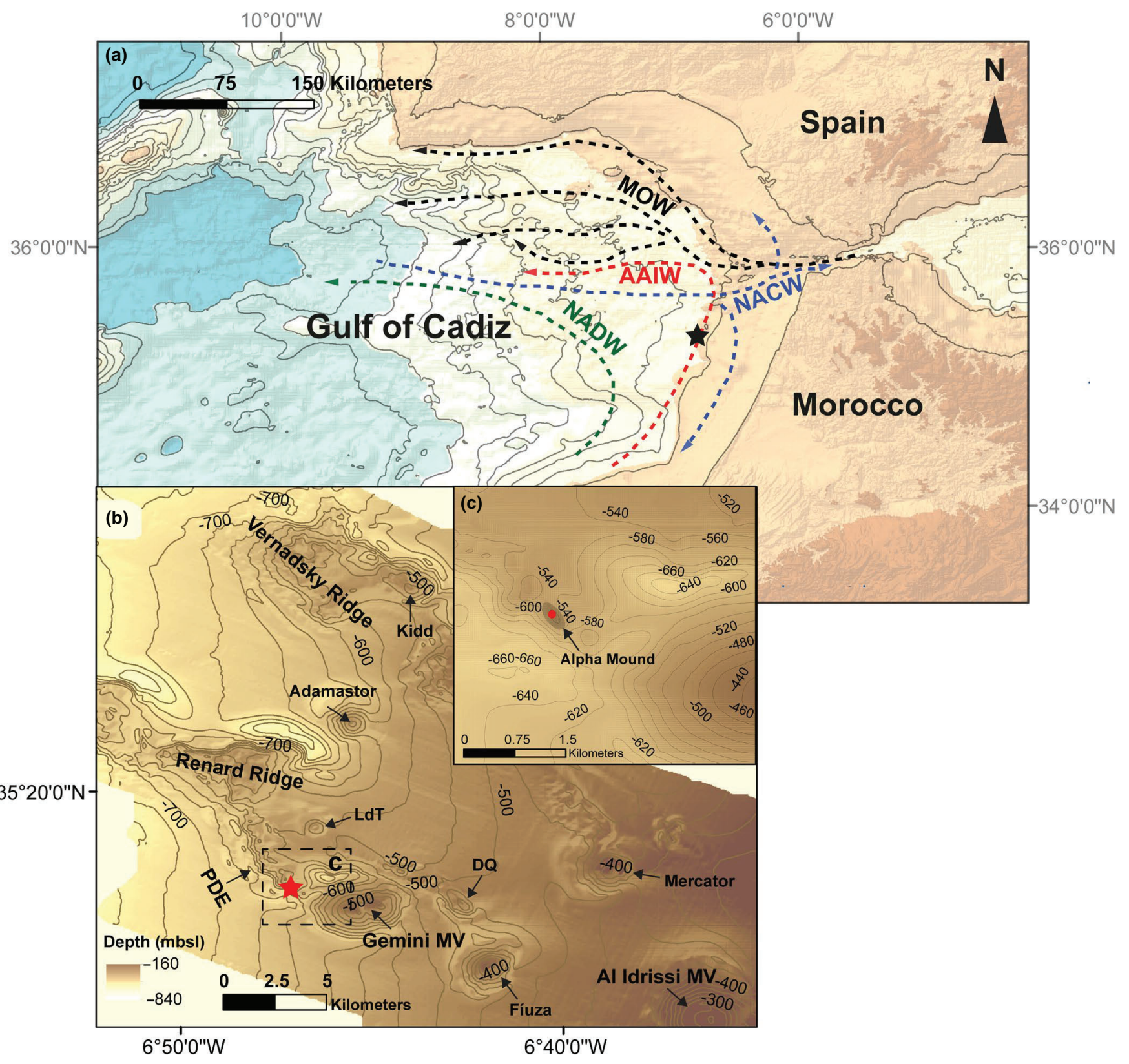

FIGURE 1 (a) Map of the study site (black asterisk) in the Gulf of Cadiz. North Atlantic Central Water (NACW), Mediterranean Outflow Water (MOW), Antarctic Intermediate Water (AAIW) and North Atlantic Deep Water (NADW) are indicated. (b) Map showing the El Arraiche mud volcano (MV) field, including the Vernadsky and Renard Ridge, the Pen Duick Escarpment (PDE) and the eight mud volcanoes Al Idrissi, Gemini, Don Quichote (DQ), Fíuza, Mercator, Lazarillo de Tormes (LdT), Adamastor and Kidd. Seafloor bathymetry is in metres below sealevel (mbsl). Bathymetry is from Van Rensbergen, et al. (2005). Alpha Mound (red asterisk) is located on the SE edge of the PDE. (c) Close-up of Alpha Mound with the location of gravity core MD13-3443G (red dot) retrieved during the MD194 EuroFLEETS GATEWAYS expedition onboard the R/V Marion Dufresne [Colour figure can be viewed at wileyonlinelibrary.com]

and gentle homogenization, bulk sediment samples were dispersed onto zero-background silicon sample holders and scanned from $5^{\circ}$ to $70^{\circ} 2 \theta$ at $40 \mathrm{kV}$ and $40 \mathrm{~mA}$, with a step size of $0.01^{\circ}$ and a scan speed of $4^{\circ} \mathrm{min}^{-1}$, using $\mathrm{Cu}-\mathrm{K}_{\alpha}$ radiation. Peak fitting and identification were carried out with the Rigaku software X-PDL linked to the Database of the International Centre for Diffraction Data (ICDD). Quantitative phase contents were determined by Rietveld refinement using TOPAS 4 and 5 software (Bruker). Calcium ( $\mathrm{Ca}$ ) and magnesium ( $\mathrm{Mg}$ ) contents in dolomite and calcite were calculated based on $\mathrm{d}_{104^{-}}$-values and unit cell volumes, respectively. The relationship between Ca content of dolomite and the $\mathrm{d}_{104}$-value was provided by Lumsden (1979) as $\mathrm{NCaCO}_{3}=333.33 d-911.99$, where $\mathrm{NCaCO}_{3}$ is the $\mathrm{mol} \% \mathrm{CaCO}_{3}$ and $d$ is the $\mathrm{d}_{104}$ lattice spacing in $\AA$ calculated from the position of the (104) reflection (Gregg, Bish, Kaczmarek, \& Machel, 2015). The Mg content of calcite was obtained from the unit cell volume derived from the refined lattice parameters using the calibration of Titschack, Goetz-Neunhoeffer, and Neubauer (2011). The relationship between $\mathrm{Mg}$ content in $\mathrm{mol} \%, \mathrm{Mg}_{\text {cal }}$, and 
unit cell volume $\mathrm{V}_{\text {cal }}$ is given by the latter as $\mathrm{Mg}_{\text {cal }}=1.047482 \mathrm{~V}_{\text {cal }}+$ 385.628601 .

\section{3 | Petrographic analysis}

Petrographic thin-sections were prepared from the semi-lithified CWC mound sediment at $480 \mathrm{~cm}$ depth using glass slides and epoxy resin. They were analysed using both optical microscopy, with a Leica DM4500P polarized light microscope, and cathodoluminescence $(\mathrm{CL})$ microscopy, using a standard petrographic microscope equipped with a Cambridge CLmk3A device operated at $12 \mathrm{kV}$ and $450 \mathrm{~mA}$. Samples of the semi-lithified CWC mound sediment at 480 , 482 and $490 \mathrm{~cm}$ depth were prepared for scanning electron microscopy (SEM) analyses. SEM imaging was conducted with a FEI XL30 Sirion FEG field emission microscope equipped with a secondary electron and backscatter detector using 20-25 kV acceleration tension and with a Phenom desktop SEM.

\section{4 | Lipid biomarker analysis}

Twelve samples were analysed from core MD13-3443G for lipid biomarkers, from 2, 70, 167, 265, 385, 425, 445, 465, 485, 525, 565 and $595 \mathrm{~cm}$ depth. Preparation and extraction of lipid biomarkers were performed according to previously published methods (Birgel \& Peckmann, 2008; Birgel et al., 2006). Sediment samples for lipid analyses were saponified with $6 \% \mathrm{KOH}$ in methanol to extract esterbound fatty acids and were collected in a separatory funnel. Prior to saponification, $20 \mu \mathrm{g}$ of $5 \alpha$-cholestane (hydrocarbons), 1-nonadecanol (alcohols) and 2-methylated $\mathrm{C}_{18}$ carboxylic acid were added as internal standards. Samples were then extracted with a mixture of dichloromethane and methanol (3:1). MilliQ water was added to the combined extracts (including the saponification extract), acidified with $10 \% \mathrm{HCl}$ in water to $\mathrm{pH}=2$, to transfer the fatty acid salts to the organic phase in the separatory funnel. After collecting and drying the total lipid extract (TLE) under a stream of nitrogen, the organic extracts were separated into four fractions of increasing polarity using Supelco-LC-NH2 glass cartridges (500 mg sorbent) with a sequence of solvents of increasing polarity: (a) hydrocarbons, $4 \mathrm{ml}$ n-hexane, (b) ketones/esters, $6 \mathrm{ml}$-hexane/DCM 3:1, (c) alcohols, $7 \mathrm{ml} \mathrm{DCM}$ /acetone 9:1 and (d) carboxylic acids, $2 \mathrm{ml} 2 \%$ formic acid in DCM. Alcohol fractions were silylated with N,O-bis(trimethylsilyl) trifluoracetamide (BSTFA) and pyridine (1:1) and analysed as their trimethylsilyl ether (TMS) derivatives. Carboxylic acids were analysed as their methyl esters (ME). Carboxylic acid methyl esters (FAMEs) were prepared from free carboxylic acids with $20 \%$ boron trifluoride in methanol in a screw-cap vial $\left(1 \mathrm{hr}, 70^{\circ} \mathrm{C}\right)$. All fractions were examined by coupled gas chromatography-mass spectrometry using an Agilent 7890 A GC system coupled to an Agilent 5975C inert MSD mass spectrometer at the University of Vienna. Quantification was done using GC-FID (gas chromatography-flame ionization detection) with an Agilent 7820 A GC system. Both GC systems were equipped with HP-5 MS UI fused silica columns ( $30 \mathrm{~m} \times 0.25 \mathrm{~mm}$ i.d., $0.25 \mu \mathrm{m}$ film thickness). Helium was used as the carrier gas. The temperature program was: $60^{\circ} \mathrm{C}$ for $1 \mathrm{~min}$ to $150^{\circ} \mathrm{C}$ at $10^{\circ} \mathrm{C} / \mathrm{min}$, then to $230^{\circ} \mathrm{C}$ at $10^{\circ} \mathrm{C} / \mathrm{min}$ for $25 \mathrm{~min}$.

For examination of the GDGTs, aliquots of the total lipid extract were pre-separated from the DCM-soluble asphaltene fraction (Birgel et al., 2014) and were analysed with a Varian MS workstation $6.91 \mathrm{HPLC}$ system coupled to a Varian 1200L triple quadrupole mass spectrometer via an atmospheric pressure chemical ionization interface at the University of Hamburg (Baumann et al., 2018). For the analysis of GDGT-derived biphytanes, isoprenoid tetraethers were subjected to ether cleavage as described by Schouten, Hoefs, Koopmans, Bosch, and Sinninghe Damsté (1998) and modified after Birgel et al. (2014). The resulting biphytanes were identified using a Thermo Scientific Trace GC Ultra coupled to a Thermo Scientific DSQ II mass spectrometer at the University of Hamburg. The measuring conditions were identical as those described above.

Compound-specific stable carbon isotope analyses of the alcohols were performed using a Thermo Fisher Trace GC Ultra connected via a Thermo Fisher GC Isolink interface to a Thermo Fisher Delta V Advantage spectrometer at the University of Vienna. Ether-cleaved biphytanes were measured with an Agilent $6890 \mathrm{GC}$ coupled with a Thermo Finnigan Combustion III interface to a Finnigan Delta Plus $\mathrm{XL}$ isotope ratio mass spectrometer at the University of Hamburg. All organic compound-specific carbon isotope values are expressed in $\delta$ notation in per mil (\%o) relative to the Vienna Pee Dee Belemnite (VPDB) standard and were corrected for additional carbon introduced after derivatization with BSTFA to TMS derivatives. The analytical error of the isotope measurements on both instruments was $\pm 0.8 \%$. Identification of individual organic compounds was based on retention times and published mass spectra. Based on the weight of the extract versus the sediment samples (wet weight - dry sediment weight), lipids were quantified as nanogram per gram (ng/g) sediment sample after which weight percentages were calculated.

\subsection{Age determination of coral fragments}

In total, 15 uranium-series isotope measurements were done on two reef-forming scleractinian coral species (Lophelia pertusa and Madrepora oculata). Prior to measurements, the CWC skeletal fragments were mechanically cleaned using the sandblasting method and chemically cleaned using weak acid leaching and water rinsing as described by Frank et al. (2004) and updated by Wefing et al. (2017). The measurements were conducted at the Institute for Environmental Physics at Heidelberg University. The $U$-series isotope analyses were done by multi-collector inductively coupled plasma mass spectrometry (Thermo Fisher Neptune Plus; Wefing et al., 2017). Uraniumseries ages were computed using the half-lives provided by Cheng et al. (2000). 


\section{4 | RESULTS}

\subsection{Sediment description}

Gravity core MD13-3443G from Alpha Mound consisted of sixmetres of unlithified, mostly undisturbed CWC mound sediments (Figure 2). From 506 to $478 \mathrm{~cm}$ depth, the sediment was semilithified and appeared whiter in colour. The mound sediments were composed of a mixed carbonate and siliciclastic matrix with intervals containing varying amounts of aragonitic CWC fragments together with other bioclastic fragments of gastropods, bivalves and foraminifera. The CWC assemblage was mainly comprised of the scleractinian coral species Lophelia pertusa, Madrepora oculata, Desmophyllum spp. and Dendrophyllia spp. Typical matrix sediment consists of mixed clay-to sand-sized carbonate and siliciclastic detrital grains but no cement.

At the bottom of core MD13-3443G (Figure 2) from 601 to $598 \mathrm{~cm}$ depth, CWC fragments occurred in slightly compacted sediments (light grey band). From 598 to $577 \mathrm{~cm}$ depth, several CWC fragments were observed in a silty clay matrix. Preservation of primary CWC features and morphologies in this interval varied from good to medium. The sediment changed at a depth of $577-507 \mathrm{~cm}$, where corals were only sporadically observed in a compact clay to silty clay-rich matrix. Few more CWCs were present from 507 to $497 \mathrm{~cm}$ depth. The CWCs and other bioclasts increased in abundance from 497 to $477 \mathrm{~cm}$. Four horizons, $2 \mathrm{~cm}$ in thickness occurred at 506, 502, 482 and $478 \mathrm{~cm}$ depths displaying brecciated fragments of previously semi-lithified sediment embedded in an unconsolidated sediment matrix. The sediment from 506 to $478 \mathrm{~cm}$ depth will henceforth be referred to as the semi-lithified zone (SLZ; Figure 2). The SLZ is clearly different from typical CWC mound sediment, which is generally unlithified and not brecciated. Coldwater coral preservation in the SLZ was poor to medium, and CWC fragments directly on top of the SLZ were corroded (467 cm depth). The sediment between 477 and $467 \mathrm{~cm}$ depth contained less abundant CWC fragments. From 467 to $428 \mathrm{~cm}$ depth, the sediment was compacted and a higher abundance of solitary corals was observed, followed by a change to colonial CWC species at $428 \mathrm{~cm}$ depth, where CWC preservation was good. From 428 to $387 \mathrm{~cm}$ depth, the CWCs were contained in a silty clay matrix. CWCs were rare from 388 to $377 \mathrm{~cm}$ depth. Few CWCs were present from 377 to $352 \mathrm{~cm}$ depth, where the sediment was silty. The CWCs were absent between 352 and $312 \mathrm{~cm}$ depth, where the sediment was more clay-rich. Few CWCs were observed again between 312 and $307 \mathrm{~cm}$ depth. From 307 to $277 \mathrm{~cm}$ depth, the sediment consisted of small CWC fragments in a silt clay matrix. The preservation of CWCs varied from medium to good and became better towards $277 \mathrm{~cm}$ depth. The sediment from 277 to $272 \mathrm{~cm}$ depth was noticeably more compact. From 277 to $252 \mathrm{~cm}$ depth an increase in CWC fragments in a silty clayey matrix was observed. CWC preservation in this interval was medium to good. From 257 to $252 \mathrm{~cm}$ depth, CWC fragments were commonly fragmented. Fewer CWCs were observed from 252 to $237 \mathrm{~cm}$ depth. The preservation of these
CWCs was medium to good. From 227 to $217 \mathrm{~cm}$ depth, small coral fragments and other small bioclasts such as bivalves and brachiopods were found. From 217 to $212 \mathrm{~cm}$ depth, there was an increase in CWC abundance; abundance subsequently declined between 212 and $197 \mathrm{~cm}$ depth, where the matrix became more clay-rich. The CWC preservation was good in this interval. Coral fragments were more abundant again between 197 and $187 \mathrm{~cm}$ depth. From 177 to $157 \mathrm{~cm}$ depth, CWC fragments were observed with other bioclasts in a clay matrix and CWC preservation was medium to good. From 157 to $90 \mathrm{~cm}$ depth, few CWCs were present and the matrix was muddy. From 135 to $125 \mathrm{~cm}$ depth, the sandy to siltsized sediment was poorly sorted and dominated by foraminifera. CWCs were present again from 90 to $77 \mathrm{~cm}$ depth. At 77 to $63 \mathrm{~cm}$ depth, CWC abundance decreased and increased again at 63 to $10 \mathrm{~cm}$ depth. Overall, CWC preservation in this interval was good. In the top $10 \mathrm{~cm}$ of the core, no CWC fragments were present; the sediment from 20 to $0 \mathrm{~cm}$ depth was yellowish brown. On the seafloor, only coral debris was observed, and no living corals were present.

\section{2 | Mineralogy}

The mineralogy of the matrix (for definition see Section 4.1) reflected a mixture of siliciclastic and carbonate minerals. The detrital fraction was composed mostly of quartz, feldspar and clay minerals (i.e. muscovite and chlorite). Two dolomite phases were observed, a Ca-excess non-stoichiometric and a stoichiometric phase. Because the latter was only present in low contents (few \%) and authigenic dolomite is rarely found in young marine sediments, stoichiometric dolomite found in core MD13-3443G is considered to be of detrital origin (Pirlet et al., 2012). In total, the detrital fraction made up between 25 and 57 wt.\% of the matrix (Figure 2). Bioskeletal and authigenic carbonate phases, including aragonite, calcite, high-Mg calcite and Ca-excess dolomite made up 43-75 wt.\% of the matrix sediment. Aragonite peaks corresponded with intervals with the most abundant CWC fragments (Figure 2). Aragonite content, based on Rietveld refinement, varied up to a maximum of $19 \mathrm{wt} . \%$. Calcite in the core fluctuated around $40 \mathrm{wt} . \%$, except in the semi-lithified zone (from 506 to $478 \mathrm{~cm}$ depth), where the calcite content was between 10 and 20 wt.\%. In contrast, high-Mg calcite was exclusively present in minor amounts in the top $30 \mathrm{~cm}$ of the core with a maximum of 6 wt.\% and in the semi-lithified zone where high-Mg calcite contents reached $30 \mathrm{wt} . \%$. Calculations indicate that there was approximately $13 \mathrm{~mol} \% \mathrm{Mg}$ in the high-Mg calcite. Ca-excess dolomite contained excess $\mathrm{Ca}$ up to $9 \mathrm{~mol} \%$. Ca-excess dolomite ranged from 0 to 30 wt.\%, with a large positive excursion from 165 to $360 \mathrm{~cm}$ depth and in the semi-lithified zone from 478 to $508 \mathrm{~cm}$ depth. Additional minerals present in minor quantities throughout the core included pyrite and halite (0-2 wt.\%), of which the latter is likely an artefact due to drying of the sediment and is therefore not included in Figure 2. Gypsum was present in minor quantities at 478 and $530 \mathrm{~cm}$ depth, but too little to allow for quantification. 

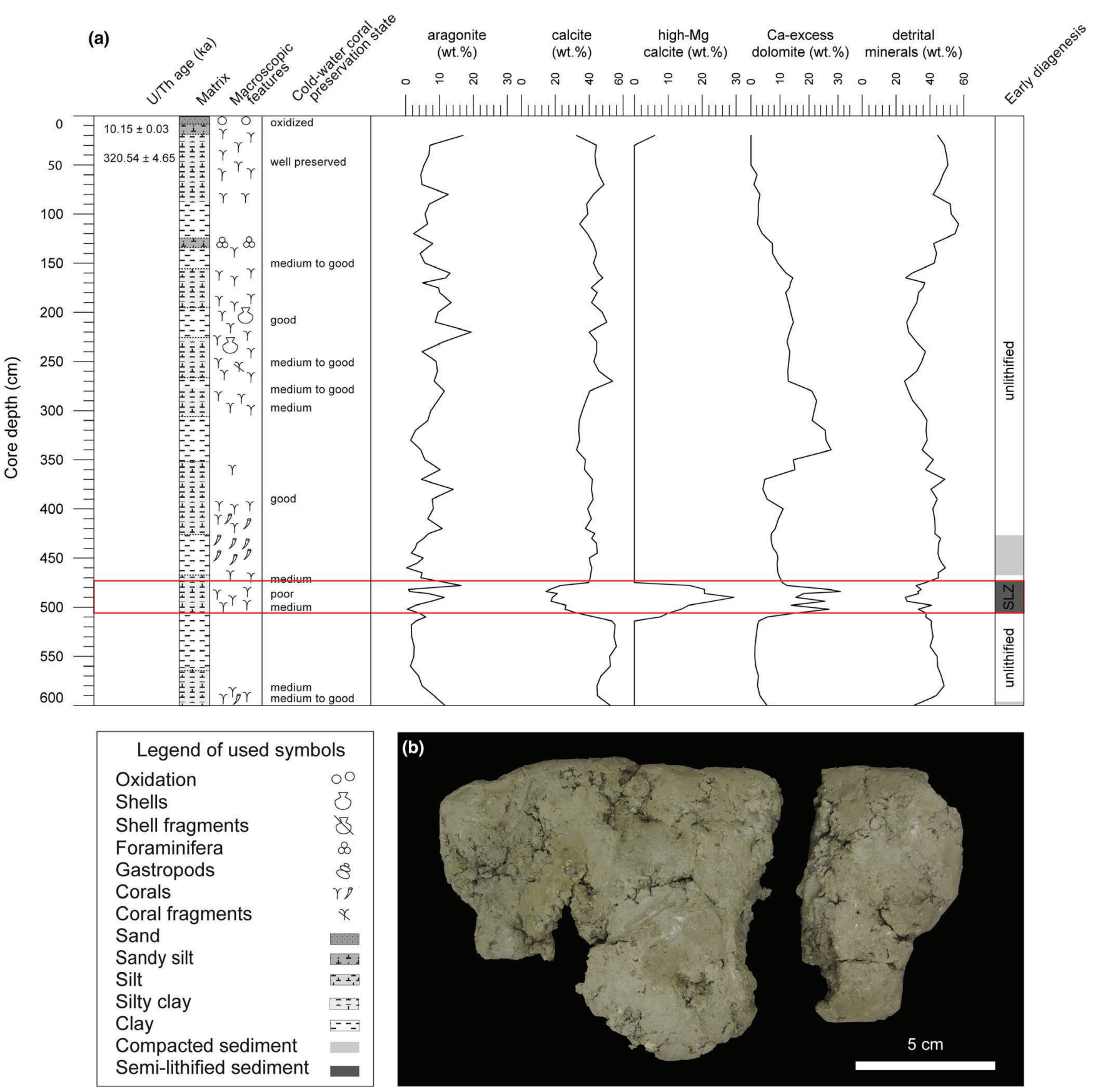

FIGURE 2 (a) Stratigraphic log and mineralogy of core MD13-3443G. Uranium-thorium (U/Th) ages of the cold-water corals (CWCs) are indicated. Sediment consists of cold-water coral (CWC) skeletons and other bioclasts, embedded in a mixed calcareous/siliciclastic matrix. Other bioclasts include bivalves, gastropods and foraminifera. Typical matrix sediment consists of mixed clay-to sand-sized carbonate and siliciclastic detrital grains, but no cement. The coral preservation state is described according to Foubert and Henriet (2009). Oxidation of the CWC mound sediment is indicated by a reddish to brownish coating. Displayed are weight percentages (wt.\%) of aragonite, calcite, high-Mg calcite, Ca-excess dolomite and detrital minerals; all based on quantitative analyses of X-ray diffraction data (XRD). Detrital components consist of quartz, feldspar, stoichiometric dolomite and clays. Highlighted sections indicate zones of compaction (light grey) and semi-lithification (dark grey). (b) Photograph of the semi-lithified sediment. SLZ, semi-lithified zone [Colour figure can be viewed at wileyonlinelibrary.com]

\subsection{Sedimentary petrography of the semi- lithified horizon}

Cold-water coral mound sediment at $480 \mathrm{~cm}$ depth revealed the presence of aragonite needles within the voids of CWC skeletons
(Figure 3a) and numerous small $(<5 \mu \mathrm{m})$ rhombohedral crystals in the semi-lithified matrix sediment surrounding the CWC skeletal clasts, which were interpreted as high-Mg calcite (Figure 3b). Larger $(10-20 \mu \mathrm{m})$ rhombohedral crystals showed bright orange luminescence (Figure 3c) and were interpreted as Ca-excess 
dolomite. These crystals were observed in the unlithified matrix (Figure 3d). Brecciation of the semi-lithified sediment was observed (Figure 3e). Linear features in the CWC skeleton (Figure 3f) were likely signs of fabric selective dissolution. Irregular (Figure 3g) and circular features (Figure 3h) penetrated the semi-lithified sediment and were possibly formed through (bio-)erosive processes such as borings.

\section{4 | Lipid biomarkers}

Contents of organic compounds in the alcohol fractions were derived from GC-FID and are given in ng/g sediment (Table 1 and Figure $4 a, b)$. Among the most abundant organic compounds were $n$-alcohols with 26 to 28 carbons (Figure 5a). Cyclic terpenoids such as sterols (brassicasterol and dinosterol) and geohopanoids (bis-homohopanol and anhydrobacteriohopanetetrol = anhydro$\mathrm{BHT}$ ) were found as well. Brassicasterol and dinosterol were present at all sample depths. Bis-homohopanol was present in most samples, but was absent at 167 and $265 \mathrm{~cm}$ depth. Anhydro-BHT was only observed at 445 and $465 \mathrm{~cm}$ depth. Further, non-isoprenoidal monoalkyl glycerol ethers (MAGE) with 15 and 17 carbon atoms were only found close to the sediment-seawater interface at $2 \mathrm{~cm}$ depth. Dialkyl glycerol ethers (DAGEs) were present, which comprised 30 carbons in the side chains (15 carbons per chain). Three prominent DAGEs were observed, namely (a) iso$\mathrm{C}_{15}$ /iso- $\mathrm{C}_{15}$, (b) iso- $\mathrm{C}_{15}$ /anteiso- $\mathrm{C}_{15}$ and (c) anteiso- $\mathrm{C}_{15}$ /anteiso- $\mathrm{C}_{15}$ (i.e. DAGE $\mathrm{C}_{30 \mathrm{a}-\mathrm{c}}$ ). Prefixes iso- and anteiso- describe the methylgroup branching point at the penultimate and ante-penultimate carbon atom, respectively. DAGEs $\mathrm{C}_{30 \mathrm{a}-\mathrm{c}}$ were found at all depths (with exception of the sediment-surface interface), but DAGE $C_{30 a}$ and DAGE $C_{30 b}$ co-eluted with other, unidentified organic compounds at 425, 445, 465, 525, 565 and $595 \mathrm{~cm}$ depths. Overall, DAGEs were relatively abundant at 167, 265 and $485 \mathrm{~cm}$ depths. Another ether lipid present was the isoprenoidal diphytanyl glycerol diether archaeol. Archaeol was especially prominent in the lower section of the core, namely at 425, 445, 465, 485, 565 and $595 \mathrm{~cm}$ depth. Increased archaeol contents were detected at 485 and $595 \mathrm{~cm}$ depth. Biphytanediols bp-0, bp-1, bp-2 and bp-3 occurred at 2, 385, 425, 445, 465, 525, 565 and $595 \mathrm{~cm}$ depth, but were found in traces only ( $<50 \mathrm{ng} / \mathrm{g}$ sediment) at 70,167, 265 and $485 \mathrm{~cm}$ depths. Because the other fractions (hydrocarbons and carboxylic acids) did not show a strong signal of AOM (i.e. isoprenoid hydrocarbons and terminally branched carboxylic acids; Tables S1, S2), only the alcohol fraction will be discussed in the following.

Of the various glycerol dibiphytanyl glycerol tetraethers (GDGTs), acyclic (GDGT-0), monocyclic (GDGT-1), bicyclic (GDGT2), tricyclic (GDGT-3) and the pentacyclic crenarchaeol (GDGT-5) and its isomer crenarchaeol' (GDGT-5') were identified (Table 1). GDGTs of the sample at $265 \mathrm{~cm}$ depth were lost during preparation in the laboratory. All samples contained various amounts of GDGT-1 to GDGT-3, crenarchaeol and crenarchaeol', yet GDGT-0 was the most abundant (Figure $5 \mathrm{~b}$ ). The relative percentages of GDGT-0 to GDGT-3 were elevated for $485 \mathrm{~cm}$ depth, where GDGT-2 comprised $25 \%$ of all GDGTs, a higher content than at all other depths. The GDGT-0/crenarchaeol and GDGT-2/crenarchaeol ratios are provided in Table 2. These ratios have been used to distinguish between the contribution of marine benthic archaea (GDGT-0 to -3 predominant) and planktonic archaea (GDGT-0 and crenarchaeol predominant). Most samples had GDGT-0/crenarchaeol ratios between 1 and 2 and GDGT-2/crenarchaeol ratios of $<1$. At $485 \mathrm{~cm}$ depth, the GDGT-0/crenarchaeol and GDGT-2/ crenarchaeol ratio were relatively high, namely 2.8 and 1.8 , respectively.

The $\delta^{13} \mathrm{C}$ values of the $n$-alcohols varied from $-33 \%$ to $-28 \%$ (Table 1). The isotopic compositions of sterols showed a somewhat higher variation with values ranging from $-31 \%$ o to $-24 \%$ o for brassicasterol and $-28 \%$ to $-23 \%$ of dinosterol. The isotopic composition of DAGE $\mathrm{C}_{30 \mathrm{a}-\mathrm{b}}$ were only obtained for the sample at $385 \mathrm{~cm}$ depth, which were $-38 \%$ for DAGE $\mathrm{C}_{30 \mathrm{a}}$ and $-37 \%$ for DAGE $\mathrm{C}_{30 \mathrm{~b}}$. Values of DAGE $\mathrm{C}_{30 \mathrm{c}}$ ranged from $-82 \%$ to $-29 \%$, with a relatively low value (i.e. $\leq-82 \%$ ) at $485 \mathrm{~cm}$ depth. The lowest value of $-82 \%$ was determined for the sample from $485 \mathrm{~cm}$ depth. Bishomohopanol values ranged from $-56 \%$ o to $-25 \%$, but values were overall close to $-30 \%$ with the exception of $-56 \%$ at $485 \mathrm{~cm}$ depth. The $\delta^{13} \mathrm{C}$ values of archaeol could be obtained only at $425,445,465$ and $595 \mathrm{~cm}$ depths, ranging widely from $-71 \%$ o to $-26 \%$. The lowest value of $-71 \%$ was found at $595 \mathrm{~cm}$ depth. Values of the biphytane-diols ranged from $-22 \%$ o to $-18 \%$; (a) bp-0 ranged from $-21 \%$ o to $-18 \%$, (b) bp-2 ranged from $-22 \%$ o to $-20 \%$ and (c) bp-3 ranged from $-19 \%$ to $-18 \%$. Values of bp-1 could not be determined due to its low contents.

The $\delta^{13} \mathrm{C}$ values of the GDGTs were measured as their ethercleaved biphytanes (Table 1). Samples at 2, 70 and $167 \mathrm{~cm}$ depths were not analysed for $\delta^{13} \mathrm{C}$ values due to low content of GDGTs.

FIGURE 3 (a) SEM-SE image of aragonite needles at the surface of a CWC skeleton (arrow); $490 \mathrm{~cm}$ depth. (b) SEM-SE image of rhombohedral crystals; $482 \mathrm{~cm}$ depth. (c) Cathodoluminescence micrograph of rhombic crystal (arrow) showing bright orange luminescence. This phase has been interpreted as Ca-excess dolomite. Other fragments, corresponding with (irregular) bioclasts, reveal a dull, reddish luminescence. Dashed white lines represent the limits between semi-lithified and unlithified matrix; $480 \mathrm{~cm}$ depth. (d) Plane-polarized light photomicrograph of the same area as in c. (e) Cross-polarized light photomicrograph of semi-lithified, brecciated fragments (indicated by arrows); $480 \mathrm{~cm}$ depth. (f) SEM-SE image of linear, parallel structures (arrows) indicating the dissolution of CWC skeleton; $490 \mathrm{~cm}$ depth. (g) Plane-polarized photomicrograph of irregular features (arrows) penetrating the semi-lithified fabric, indicating (bio-)erosive processes; $480 \mathrm{~cm}$ depth. (h) Plane-polarized photomicrograph of circular structures (arrows) in the semi-lithified fabric that are likely the result of borings; $480 \mathrm{~cm}$ depth. CWC, cold-water coral; SEM-SE, Scanning Electron Microscopy-Secondary Electrons [Colour figure can be viewed at wileyonlinelibrary.com] 
TABLE 1 Contents of alcohols and glycerol dibiphytanyl glycerol tetraethers (GDGTs) in ng/g sediment

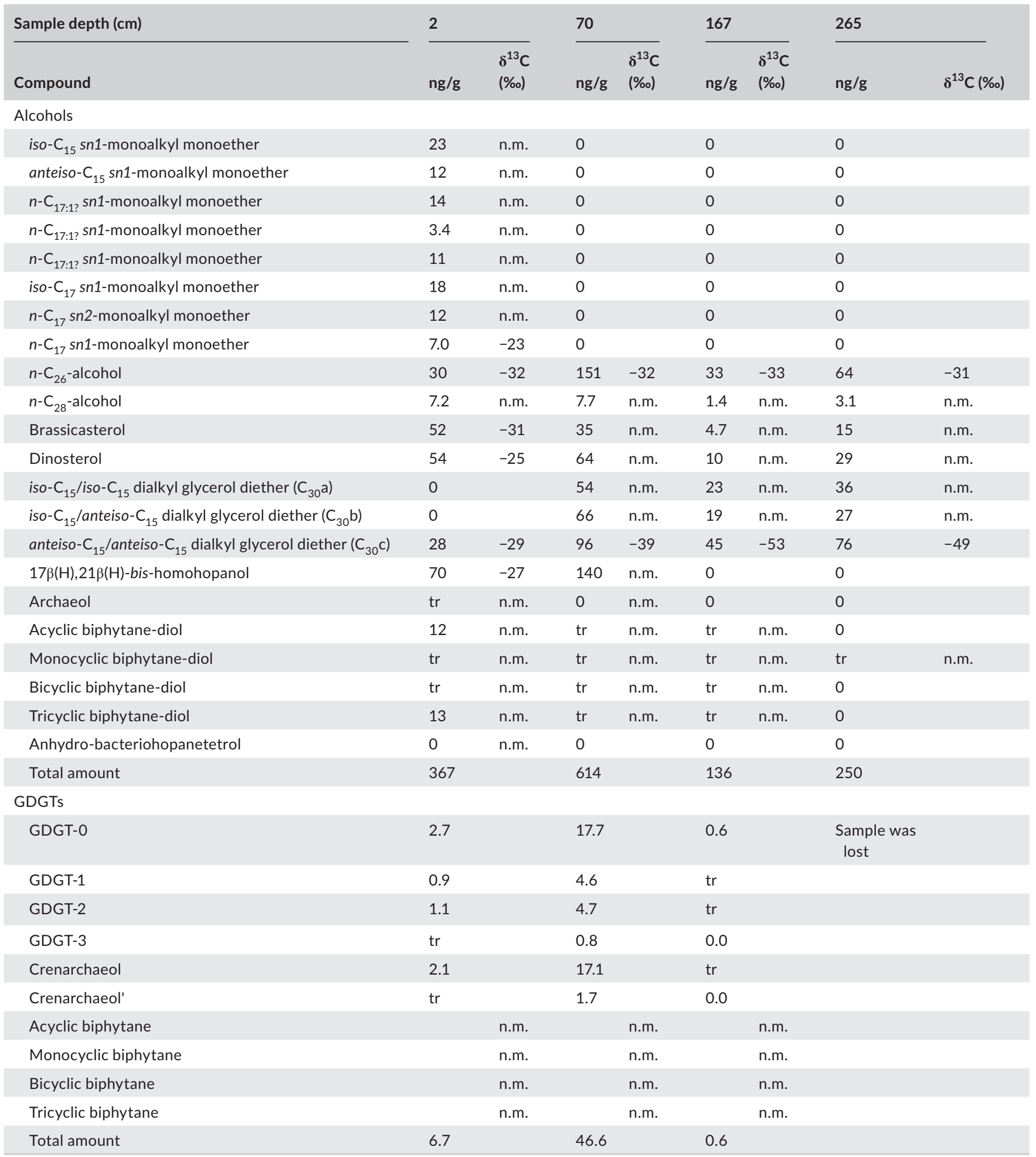

Note: The $\delta^{13} \mathrm{C}$ isotope values of organic compounds are in \% vs. V-PDB. The $\delta^{13} \mathrm{C}$ values of the GDGTs were measured as their ether-cleaved biphytanes. Acyclic biphytane is derived from GDGT-0 to GDGT-1, monocyclic from GDGT-1, GDGT-2 to GDGT-3, bicyclic from GDGT-3 to GDGT-4 and tricyclic from crenarchaeol (GDGT-5). Prefixes iso- and anteiso- describe the methyl-group branching point at the penultimate and antepenultimate carbon atom, respectively. tr, traces ( $<50 \mathrm{ng} / \mathrm{g}$ sediment); co, co-elution with other organic compounds; n.m., not measurable due to low content.

Tricyclic biphytane (only crenarchaeol-derived) yielded values from $-21 \%$ o to $-20 \%$. All other biphytanes showed stronger variations in various samples. Bicyclic biphytane (GDGT-3 and crenarchaeol-derived) showed relatively uniform values from $-22 \%$ to $-20 \%$, except at 485 and $595 \mathrm{~cm}$ depth, where lower values of $-51 \%$ and $-28 \%$ o were obtained. The most significant 


\begin{tabular}{|c|c|c|c|c|c|c|c|c|c|c|c|c|c|c|c|}
\hline \multicolumn{2}{|l|}{385} & \multicolumn{2}{|l|}{425} & \multicolumn{2}{|l|}{445} & \multicolumn{2}{|l|}{465} & \multicolumn{2}{|l|}{485} & \multicolumn{2}{|l|}{525} & \multicolumn{2}{|l|}{565} & \multicolumn{2}{|l|}{595} \\
\hline $\mathrm{ng} / \mathrm{g}$ & $\begin{array}{l}\delta^{13} \mathrm{C} \\
(\% \circ)\end{array}$ & $\mathrm{ng} / \mathrm{g}$ & $\begin{array}{l}\delta^{13} \mathrm{C} \\
(\% \circ)\end{array}$ & $\mathrm{ng} / \mathrm{g}$ & $\begin{array}{l}\delta^{13} \mathrm{C} \\
(\% \circ)\end{array}$ & $\mathrm{ng} / \mathrm{g}$ & $\begin{array}{l}\delta^{13} \mathrm{C} \\
(\% \circ)\end{array}$ & $\mathrm{ng} / \mathrm{g}$ & $\begin{array}{l}\delta^{13} \mathrm{C} \\
(\% \circ)\end{array}$ & $\mathrm{ng} / \mathrm{g}$ & $\begin{array}{l}\delta^{13} \mathrm{C} \\
\text { (\%०) }\end{array}$ & $\mathrm{ng} / \mathrm{g}$ & $\begin{array}{l}\delta^{13} \mathrm{C} \\
(\% \circ)\end{array}$ & $\mathrm{ng} / \mathrm{g}$ & $\begin{array}{l}\delta^{13} \mathrm{C} \\
\text { (\%o) }\end{array}$ \\
\hline 0 & & 0 & & 0 & & 0 & & 0 & & 0 & & 0 & & 0 & \\
\hline 0 & & 0 & & 0 & & 0 & & 0 & & 0 & & 0 & & 0 & \\
\hline 0 & & 0 & & 0 & & 0 & & 0 & & 0 & & 0 & & 0 & \\
\hline 0 & & 0 & & 0 & & 0 & & 0 & & 0 & & 0 & & 0 & \\
\hline 0 & & 0 & & 0 & & 0 & & 0 & & 0 & & 0 & & 0 & \\
\hline 0 & & 0 & & 0 & & 0 & & 0 & & 0 & & 0 & & 0 & \\
\hline 0 & & 0 & & 0 & & 0 & & 0 & & 0 & & 0 & & 0 & \\
\hline 0 & & 0 & & 0 & & 0 & & 0 & & 0 & & 0 & & 0 & \\
\hline 200 & -32 & 221 & -29 & 175 & -28 & 196 & -29 & 130 & -31 & 157 & -31 & 101 & -31 & 63 & -31 \\
\hline 11 & n.m. & 11 & n.m. & 9.1 & n.m. & 10 & & 6 & n.m. & 5.7 & n.m. & 4 & n.m. & 2.9 & n.m. \\
\hline 56 & -25 & 52 & -27 & 35 & -25 & 64 & -25 & 22 & -30 & 39 & n.m. & 32 & -25 & 15 & -24 \\
\hline 106 & -28 & 224 & -27 & 209 & -27 & 404 & -28 & 49 & n.m. & 142 & -23 & 149 & -24 & 51 & -25 \\
\hline 47 & -38 & $\mathrm{CO}$ & & $\mathrm{CO}$ & & $\mathrm{CO}$ & & 35 & n.m. & co & & $\mathrm{CO}$ & & co & \\
\hline 61 & -37 & $\mathrm{CO}$ & & $\mathrm{CO}$ & & $\mathrm{CO}$ & & 47 & n.m. & $\mathrm{CO}$ & & $\mathrm{CO}$ & & $\mathrm{CO}$ & \\
\hline 127 & -53 & 255 & -50 & 157 & -37 & 253 & -40 & 110 & -82 & 137 & -39 & 98 & -34 & 60 & -45 \\
\hline 26 & n.m. & 81 & -29 & 69 & -25 & 85 & -28 & 64 & -56 & 72 & -25 & 65 & -25 & 29 & -32 \\
\hline 27 & n.m. & 59 & -37 & 41 & -26 & 57 & -29 & 32 & n.m. & 33 & n.m. & 35 & n.m. & 29 & -71 \\
\hline 50 & -21 & 223 & -19 & 144 & -19 & 193 & -20 & 0 & & 71 & -18 & 34 & -18 & 28 & -21 \\
\hline 0 & & 29 & n.m. & 14 & n.m. & 22 & n.m. & 0 & & 34 & n.m. & 0 & & 19 & n.m. \\
\hline 0 & & 0 & & 20 & -26 & 22 & n.m. & 0 & & 0 & & 0 & & 0 & \\
\hline 793 & & 1,517 & & 1,128 & & 1,594 & & 537 & & 878 & & 616 & & 385 & \\
\hline 26.1 & & 27.4 & & 27.7 & & 27.6 & & 19.3 & & 10.2 & & 12.8 & & 16.0 & \\
\hline 7.1 & & 5.5 & & 5.0 & & 5.7 & & 8.0 & & 2.4 & & 2.5 & & 5.7 & \\
\hline 6.0 & & 3.8 & & 2.7 & & 4.7 & & 12.3 & & 2.4 & & 2.3 & & 6.1 & \\
\hline 0.9 & & 0.7 & & 0.6 & & 0.6 & & 2.7 & & $\operatorname{tr}$ & & $\operatorname{tr}$ & & 0.9 & \\
\hline 17.8 & & 20.0 & & 17.9 & & 18.0 & & 6.9 & & 7.9 & & 9.0 & & 11.3 & \\
\hline 1.9 & & 1.3 & & 1.0 & & 1.2 & & $\operatorname{tr}$ & & 0.8 & & 0.7 & & 0.9 & \\
\hline & -23 & & -23 & & -22 & & -23 & & -75 & & -22 & & -21 & & -41 \\
\hline & -28 & & -28 & & -22 & & -28 & & -96 & & -23 & & -21 & & -54 \\
\hline & -21 & & -22 & & -22 & & -21 & & -51 & & -20 & & -20 & & -28 \\
\hline & -20 & & -21 & & -21 & & -20 & & -20 & & -20 & & -20 & & -20 \\
\hline 59.8 & & 58.7 & & 54.8 & & 57.8 & & 49.4 & & 23.7 & & 27.3 & & 41.0 & \\
\hline
\end{tabular}

variations were found in acyclic and monocyclic biphytanes, which are derived from GDGT-0, GDGT-1 or GDGT-2. The most negative values of monocyclic biphytane of $-96 \%$ and $-54 \%$ o were found at
$485 \mathrm{~cm}$ depth and $595 \mathrm{~cm}$ depth, respectively. Similarly, the most negative values of acyclic biphytane of $-75 \%$ and $-41 \%$ were found at $485 \mathrm{~cm}$ depth and $595 \mathrm{~cm}$ depth, respectively. 
(b)

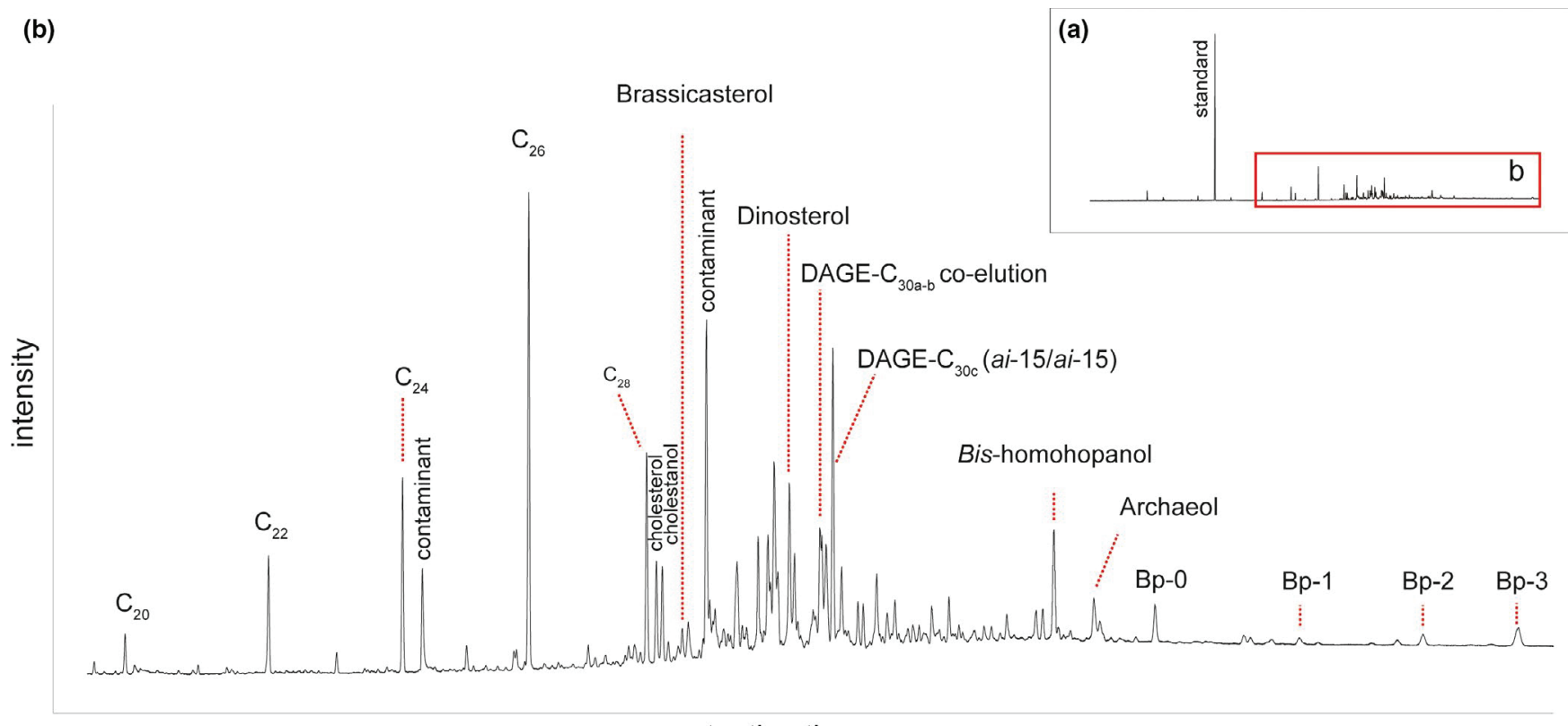

retention time

FIGURE 4 (a) GC-FID (gas chromatography-flame ionization detection) chromatogram of alcohols in CWC mound sediment (485 cm depth, core MD13-3443G). (b) Partial GC-FID chromatogram (red box). Major organic compounds found are $n$-alcohols, sterols (brassicasterol and dinosterol) and geohopanoids (bis-homohopanol), dialkyl glycerol ethers (DAGEs), archaeol and biphytane-diols (Bp). The DAGEs contain 30 carbon atoms with terminally branched iso- and anteiso-alkyl chains (15 carbons per chain). Three DAGEs were observed, namely (a) iso- $\mathrm{C}_{15}$ /iso- $\mathrm{C}_{15}$, (b) iso- $\mathrm{C}_{15}$ /anteiso- $\mathrm{C}_{15}$ and (c) anteiso- $\mathrm{C}_{15}$ /anteiso- $\mathrm{C}_{15}$ (i.e. DAGE $\mathrm{C}_{30}$ a-c). Biphytanediols are acyclic (Bp-0), monocyclic (Bp-1), bicyclic (Bp-2) and tricyclic (Bp-3). See Table 1 for more details. Contaminants displayed are phthalates [Colour figure can be viewed at wileyonlinelibrary.com]

\section{5 | Cold-water coral ages}

The radiometric dating revealed that only the top of core MD13$3443 \mathrm{G}$ at $15 \mathrm{~cm}$ depth was of Holocene age (10.15 $\pm 0.03 \mathrm{ka}$; Table 3 and Figure 2). Furthermore, an age of $320.54 \pm 4.65 \mathrm{ka}$ at $45 \mathrm{~cm}$ depth suggests much older CWCs and indicates a hiatus between 15 and $45 \mathrm{~cm}$ depth. Corals below $45 \mathrm{~cm}$ depth yielded ages between $73.21 \pm 0.23 \mathrm{ka}$ and $619.55 \pm 66.71 \mathrm{ka}$. However, we suspect strong deviation from closed system $\mathrm{U}$-series evolution. This is indicated by the fact that the $\delta^{234} \mathrm{U}$ values deviate from the expected constant seawater $\delta^{234} U$ value of $146.6 \%$ (Andersen, Stirling, Zimmermann, \& Halliday, 2010). In contrast to the above samples, the deepest coral (590 cm depth) provided a younger age and contained significantly more $U$. This sample had $58 \%$ above average $U$ content $(5.7 \mu \mathrm{g} / \mathrm{g})$ if compared to well-preserved samples from 15 to $45 \mathrm{~cm}$ depth (Table 3). Moreover, the measured $\delta^{234} U$ value was low, but similar to the apparently older but poorly preserved samples (all samples below $45 \mathrm{~cm}$ depth). Therefore, this sample was likely of similar age as the samples above, but clearly manifested strong evidence of $\mathrm{U}$-series open system behaviour and in particular $\mathrm{U}$ uptake. At $305 \mathrm{~cm}$ depth, the radiometric age was beyond the upper age limit of the $\mathrm{U} / \mathrm{Th}$ radiometric dating system, possibly indicative of $U$ loss, resulting in ${ }^{230} \mathrm{Th} /{ }^{238} \mathrm{U}$ that exceeded equilibrium values. Nevertheless, the deeper part of the core (from 255 to $590 \mathrm{~cm}$ depth) is likely of a similar age to the coral at $45 \mathrm{~cm}$ depth. Ages can be estimated using the decay of ${ }^{234} \mathrm{U}$ and its deviation from a presumed constant seawater value. Assuming a $\pm 10 \%$ o variability of modern $\delta^{234} \mathrm{U}$ through the past $400 \mathrm{ka},{ }^{234} \mathrm{U}$ ages range between 250 and $340 \mathrm{ka}$, with large uncertainties of typically more than $30 \mathrm{ka}$. Alternatively, a U-series open system model can be used to determine U/Th ages for the diagenetically altered samples, which yields ages spanning from 100 to $460 \mathrm{ka}$. This approach also suggests that samples are not in stratigraphic order (given a CWC age of $320.54 \pm 4.65 \mathrm{ka}$ at $45 \mathrm{~cm}$ depth). Therefore, below $45 \mathrm{~cm}$, radiometric ages reflect strong $\mathrm{U}$-series open system perturbations resulting from coral skeleton diagenesis. Consequently, these ages have not been further considered for chronostratigraphic purposes and only the radiometric ages of $10.15 \pm 0.03 \mathrm{ka}$ at $15 \mathrm{~cm}$ depth and $320.54 \pm 4.65 \mathrm{ka}$ at $45 \mathrm{~cm}$ depth have been considered.

\section{5 | DISCUSSION AND INTERPRETATION}

\section{1 | Mound sediment influenced by anaerobic oxidation of methane}

GDGTs are membrane lipids synthesized by many phylogenetic groups of archaea (Schouten, Hopmans, \& Sinninghe Damsté, 2013), including marine planktonic and benthic archaea. Marine planktonic archaea produce GDGTs with zero to five cyclopentane rings (Sinninghe Damsté, Schouten, Hopmans, van Duin, \& Geenevasen, 2002; Schouten et al., 1998). Crenarchaeol (GDGT-5), which contains one cyclohexane and four cyclopentane rings, is typically assigned to planktonic Thaumarchaeota in marine environments (Hoefs et al., 
FIGURE 5 (a) Organic compounds of the alcohol fraction in wt.\% grouped into $n$-alcohols $\left(\mathrm{C}_{26-28}\right)$, sterols (brassicasterol and dinosterol), dialkyl glycerol ethers (DAGE ${ }_{30 a-c}$ ), geohopanoids (bis-homohopanol and anhydro-bacteriohopanetetrol), archaeol and biphytane-diols (Bp). (b) Patterns of glycerol dibiphytanyl tetraethers (GDGTs) in wt.\%. Crenarchaeol': isomer of crenarchaeol. Crenarchaeol and crenarchaeol' are equivalent to GDGT-5 and GDGT-5', respectively [Colour figure can be viewed at wileyonlinelibrary.com]
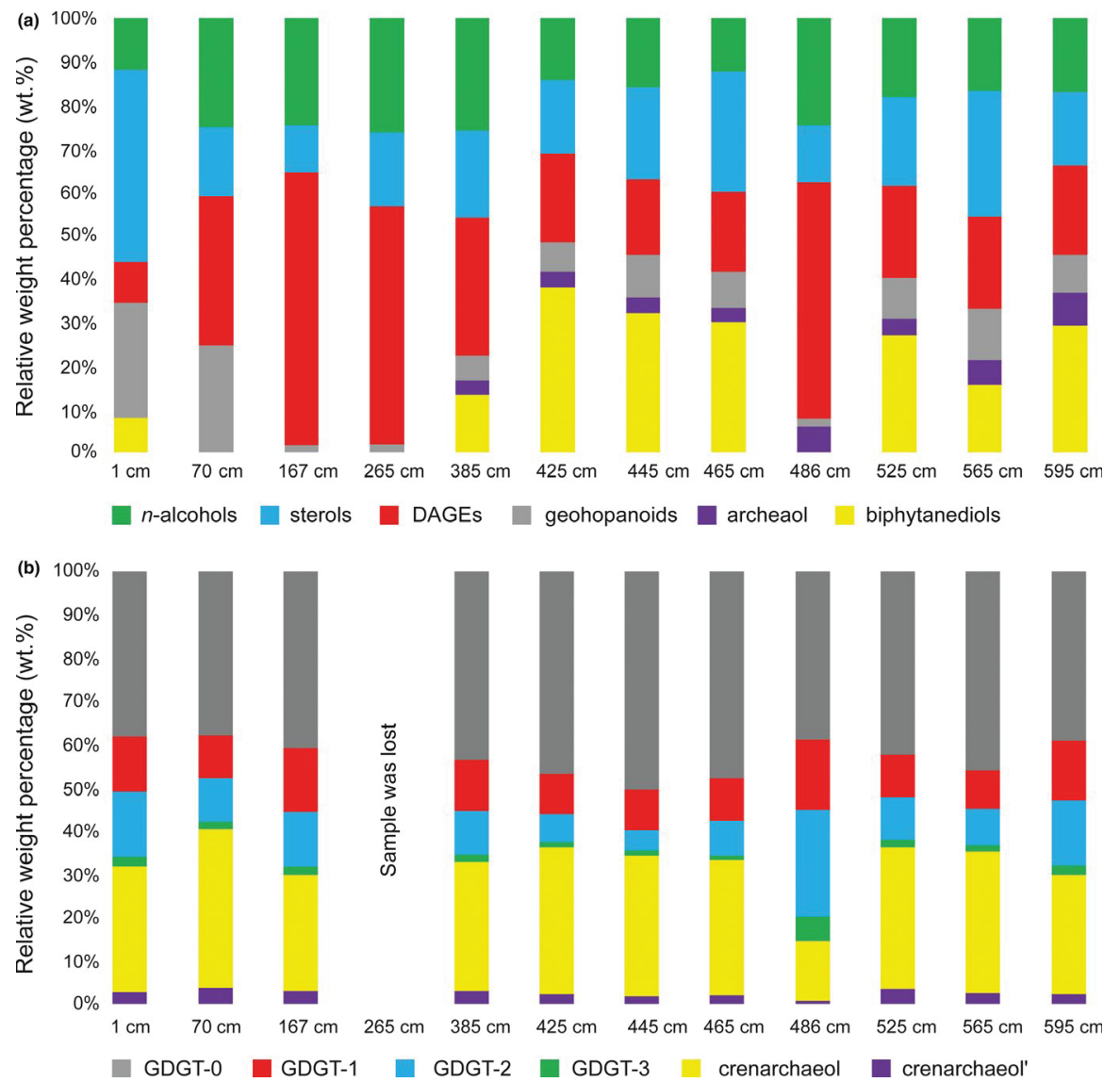

1997; Lipp, Morono, Inagaki, \& Hinrichs, 2008; Pearson et al., 2016). In contrast, GDGT-0 is present in a wide variety of archaea including methanogens (Koga, Nishihara, Morii, \& Akagawa-Matsushita, 1993; Pancost et al., 2008). It follows that GDGT-0/crenarchaeol ratios in marine sediments dominated by thaumarchaeal lipids are usually below 1 (Schouten, Hopmans, \& Sinninghe Damsté, 2013). Crenarchaeol is present throughout core MD13-3443G (Table 1 and Figure 5b), and the GDGT-0/crenarchaeol is close to 1 (with exception of $485 \mathrm{~cm}$ depth; Table 2), which confirms a major input of lipids from planktonic Thaumarchaeota. A dominant planktonic origin is further supported by $\delta^{13} \mathrm{C}$ values of $-22 \%$ o to $-20 \%$ of bi- and tricyclic biphytanes (Table 1 ), respectively, deriving from crenarchaeol (with the exception of samples at 485 and $595 \mathrm{~cm}$ depth). These values are similar to those reported from many modern marine environments (Pearson et al., 2016; Schouten et al., 2013). Thaumarchaeota are believed to fix the majority of their carbon (ca. 80\%) directly from dissolved inorganic carbon in the water column (Ingalls et al., 2006), although some carbon can be derived from suspended particulate organic matter (Pearson et al., 2016).
At $485 \mathrm{~cm}$ depth, all lipid data point towards the occurrence of AOM. Benthic archaea such as methanogens, methanotrophs and other heterotrophic archaea produce GDGTs with distinct patterns (Biddle et al., 2006; Hinrichs, Summons, Orphan, Sylva, \& Hayes, 2000). For instance, at sites where anaerobic methane-oxidizing archaea (ANME) predominates, GDGT-1 and GDGT-2 are usually most abundant (Pancost, Hopmans, \& Sinninghe Damsté, 2001; Rossel et al., 2008; Wakeham, Lewis, Hopmans, Schouten, \& Sinninghe Damsté, 2003). Elevated GDGT-2/crenarchaeol ratios have thus commonly been detected at sulphate-methane transition zones (SMTZs) where AOM is the dominant biogeochemical process (Weijers, Steinmann, Hopmans, Schouten, \& Sinninghe Damsté, 2011). Such patterns are observed in the sediment at $485 \mathrm{~cm}$ depth, which is typified by elevated GDGT-2 contents (Table 1 and Figure $5 \mathrm{~b}$ ) and shows an elevated GDGT-2/crenarchaeol ratio of 2.8 (Table 2), lending further support to the assumption that AOM occurred at this depth. Furthermore, the high GDGT-2/crenarchaeol ratio is accompanied by a strong

TAB LE 2 Glycerol dibiphytanyl glycerol tetraether (GDGT) ratios

\begin{tabular}{|c|c|c|c|c|c|c|c|c|c|c|c|}
\hline Sample depth $(\mathrm{cm})$ & 2 & 70 & 167 & 385 & 425 & 445 & 465 & 485 & 525 & 565 & 595 \\
\hline GDGT-0/crenarchaeol & 1.3 & 1.0 & 1.5 & 1.5 & 1.4 & 1.5 & 1.5 & 2.8 & 1.3 & 1.4 & 1.4 \\
\hline GDGT-2/crenarchaeol & 0.5 & 0.3 & 0.5 & 0.3 & 0.2 & 0.1 & 0.3 & 1.8 & 0.3 & 0.3 & 0.5 \\
\hline
\end{tabular}

Note: These ratios are used to distinguish between marine benthic archaea (GDGT-0 to GDGT-3 predominant) and planktonic archaea (GDGT-0 and crenarchaeol predominant). 
TABLE 3 Uranium-thorium (U/Th) ages of cold-water corals

\begin{tabular}{|c|c|c|c|c|c|c|c|c|c|}
\hline Lab code & $\begin{array}{l}\text { Sample } \\
\text { depth }(\mathrm{cm})\end{array}$ & $\begin{array}{l}\text { Coral } \\
\text { species }\end{array}$ & $\operatorname{Age}^{a}(k a)$ & $\pm(2 \sigma)$ & $\mathrm{Age}^{\mathrm{b}}(\mathrm{ka})$ & $\pm(2 \sigma)$ & ${ }^{238} \mathrm{U}(\mu \mathrm{g} / \mathrm{g})$ & $\pm(2 \sigma)$ & ${ }^{232} \mathrm{Th}$ (ng/g) \\
\hline IUP-7585 & 15 & L. pertusa & 10.16 & 0.03 & 10.15 & 0.03 & 4.45117 & 0.00018 & 0.06319 \\
\hline IUP-7586 & 45 & L. pertusa & 320.60 & 4.40 & 320.54 & 4.65 & 2.74020 & 0.00014 & 0.06675 \\
\hline IUP-7587 & 255 & L. pertusa & 619.59 & 55.14 & 619.55 & 66.71 & 3.22121 & 0.00014 & 0.60215 \\
\hline IUP-7588 & 265 & M. Oculata & 525.66 & 19.99 & 525.62 & 21.03 & 4.33782 & 0.00024 & 0.65805 \\
\hline IUP-7589 & 305 & L. pertusa & & Out of range & & & 2.93434 & 0.00015 & 0.15403 \\
\hline IUP-7590 & 365 & L. pertusa & 373.93 & 5.29 & 373.90 & 5.16 & 2.99923 & 0.00014 & 0.31522 \\
\hline IUP-7591 & 395 & L. pertusa & 430.92 & 8.84 & 430.88 & 9.67 & 3.38022 & 0.00015 & 0.65533 \\
\hline IUP-7592 & 590 & L. pertusa & 73.38 & 0.22 & 73.21 & 0.23 & 5.70921 & 0.00025 & 3.57782 \\
\hline
\end{tabular}

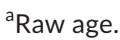

${ }^{\mathrm{b}} \mathrm{Ages}$ are corrected for the influence of seawater and/or detrital derived ${ }^{230} \mathrm{Th}$ using a ${ }^{230} \mathrm{Th} /{ }^{232} \mathrm{Th}$ ratio of $8 \pm 4$.

${ }^{c}$ Activity ratio. Lp, Lophelia pertusa; Mo, Madrepora oculata. Out of range = the radiometric age is beyond the upper age limit of the U/Th radiometric dating system. The first two U/Th ages represent closed system $\mathrm{U}$-series evolution and provide reliable age constraints. The U/Th ages below show strong deviation from closed system $\mathrm{U}$-series evolution and are likely compromised by diagenetic processes.

${ }^{13} \mathrm{C}$-depletion of GDGT-2 derived monocyclic biphytane (derived from either GDGT-1 or 2), reflected in a $\delta^{13} \mathrm{C}$ value of around $-100 \%$ (Table 1), which is characteristic of AOM (Peckmann \& Thiel, 2004). This is strengthened by the fact that the parent methane was around $-52 \%$ vs. V-PDB (Maignien et al., 2011) and the fractionation factor from methane to lipid is around $-50 \%$ o for ANMEs (cf. Niemann \& Elvert, 2008). The presence of the isoprenoidal diphytanyl glycerol diether archaeol (alcohol fraction; Table 1) and 2,6,10,15,19-pentamethylicosane (PMI; hydrocarbon fraction; Table S1) are most likely also derived from ANMEs, but methanogenic archaea cannot be ruled out because they produce the same lipids.

Because marine sediments dominated by thaumarchaeal lipids usually have a low GDGT-0/crenarchaeol ratio, a high ratio of 2.8 found at $485 \mathrm{~cm}$ in core MD13-3443G (Table 2) indicates an addition of GDGT-0 from benthic archaea to the lipid inventory. Marine sediments with high GDGT-0/crenarchaeol ratios (>2) have previously been associated with methanogenesis (Blaga, Reichart, Heiri, \& Sinninghe Damsté, 2009), because in many methanogens, GDGT-0 is the only GDGT produced. However, because of lack of other evidence for the potential presence of (fossil) methanogens, elevated GDGT-0 concentrations in Alpha Mound are most likely attributed to ANMEs. The isotopic composition of acyclic biphytane (derived from GDGT-0) is less depleted $(-75 \%$ ) than monocyclic biphytane (-96\%; Table 1$)$, likely reflecting mixing of ANMEs and Thaumarchaeota lipids, as opposed to mixing of ANMEs and methanogen lipids (Feng et al., 2014).

High GDGT-0/crenarchaeol and GDGT-2/crenarchaeol ratios observed at $485 \mathrm{~cm}$ depth were accompanied by relatively high amounts of DAGEs with two anteiso- $\mathrm{C}_{15}$ /anteiso- $\mathrm{C}_{15}$ alkyl chains (Figure $4 \mathrm{~b}$ ) and a $\delta^{13} \mathrm{C}$ value of $-82 \%$ (Table 1 ). DAGEs have commonly been interpreted as biomarkers of the sulphate-reducing bacteria associated with ANMEs (Hinrichs et al., 2000; Pancost, Bouloubassi, Aloisi, Sinninghe Damsté, \& Shipboard Scientific Party, 2001), but this inference has never been substantiated. DAGEs have not been found in enrichment cultures of sulphate-reducing bacteria of AOM consortia (Boetius et al.,
2000; Orphan, Hinrichs, et al., 2001; Orphan, House, Hinrichs, McKeegan, \& DeLong, 2001), but are common in other, chiefly hydrocarbon-degrading sulphate-reducing bacteria (Grossi et al., 2015; Vinçon-Laugier, Grossi, Pacton, Escarguel, \& Cravo-Laureau, 2016). Despite the uncertainty about the role of DAGE producers at methane seeps, their strong ${ }^{13} \mathrm{C}$ depletion confirms at least a close relationship to the AOM consortium (Blumenberg et al., 2004; Cook, Keigwin, Birgel, \& Hinrichs, 2011; Elvert, Hopmans, Treude, Boetius, \& Suess, 2005; Stadnitskaia et al., 2008; Teske et al., 2002).

Anaerobic oxidation of methane is carried out by archaea (ANMEs) that are phylogenetically related to methanogens. However, ANMEs oxidize methane instead of producing it (Krüger et al., 2003; Valentine \& Reeburgh, 2000). So far, three major groups of ANMEs (ANME-1, ANME-2 and ANME-3) have been discovered (Boetius et al., 2000; Hinrichs, Hayes, Sylva, Brewer, \& DeLong, 1999; Knittel, Lösekann, Boetius, Kort, \& Amann, 2005; Niemann et al., 2006; Niemann \& Elvert, 2008). Interestingly, the lipid biomarker pattern encountered at $485 \mathrm{~cm}$ depth points towards the dominance of archaea of the ANME-1 cluster. Archaea of the ANME-1 cluster are typified by abundant GDGTs, which is in contrast to archaea from the ANME-2 and ANME-3 clusters. The latter two clusters preferentially produce isoprenoidal dialkyl glycerol diethers such as sn-2-hydroxyarchaeol (Blumenberg et al., 2004) and the tail-to-tail linked hydrocarbons such as crocetane-lipids that are all absent at $485 \mathrm{~cm}$ depth (Table S1; Blumenberg et al., 2004; Elvert, Hopmans, Treude, Boetius, \& Suess, 2005; Niemann \& Elvert, 2008).

\section{2 | Carbonate precipitation as a result of anaerobic oxidation of methane in cold- water coral mounds}

Carbonate precipitation is a common feature of AOM-influenced sediments (Peckmann \& Thiel, 2004). In methane seep settings, carbonate precipitation occurs because of a rise in alkalinity caused 


\begin{tabular}{|c|c|c|c|c|c|c|c|c|c|}
\hline$\pm(2 \sigma)$ & $\left({ }^{230} \mathrm{Th} /{ }^{238} \mathrm{U}\right)^{\mathrm{c}}$ & $\pm(2 \sigma)$ & $\left({ }^{230} \mathrm{Th} /{ }^{232} \mathrm{Th}\right)^{\mathrm{c}}$ & $\pm(2 \sigma)$ & $\delta^{234} U_{1} \%$ & $\pm(2 \sigma)$ & $\delta^{234} U_{1} \%$ & $\pm(2 \sigma)$ & Diagenesis \\
\hline 0.00016 & 0.10162 & 0.00024 & 21,994 & 77 & 142.12 & 0.67 & 146.25 & 0.69 & No \\
\hline 0.00033 & 1.03136 & 0.00220 & 130,070 & 710 & 67.23 & 1.1 & 166.35 & 3.48 & No \\
\hline 0.00084 & 1.07602 & 0.00165 & 17,696 & 37 & 56.04 & 0.44 & 322.85 & 60.93 & Yes \\
\hline 0.00102 & 1.07989 & 0.00176 & 21,890 & 49 & 63.11 & 0.55 & 278.79 & 16.75 & Yes \\
\hline 0.00032 & 1.13696 & 0.00190 & 66,560 & 180 & 65.56 & 0.45 & & & \\
\hline 0.00056 & 1.05938 & 0.00175 & 30,949 & 75 & 70.15 & 0.50 & 201.82 & 3.28 & Yes \\
\hline 0.00107 & 1.06578 & 0.00193 & 16,867 & 41 & 62.95 & 0.58 & 212.77 & 6.14 & Yes \\
\hline 0.00583 & 0.52865 & 0.00105 & 2,589 & 7 & 73.21 & 0.52 & 90.04 & 0.64 & Yes \\
\hline
\end{tabular}

by AOM. This reaction can be described in the following terms (Reaction 1; Boetius et al., 2000; Reeburgh, 1980).

$$
\mathrm{CH}_{4}+\mathrm{SO}_{4}^{2-} \rightarrow \mathrm{HCO}_{3}^{-}+\mathrm{HS}^{-}+\mathrm{H}_{2} \mathrm{O}
$$

Methane-derived carbonates can be recognized by their distinct morphologies and ${ }^{13} \mathrm{C}$-depletion. These morphologies include slabs, pavements, irregular nodules and chimney-like features. The background sediment at seeps typically consists of fine- to coarse-grained detritus, which is cemented by authigenic micrite to form seep carbonates (Magalhães et al., 2012; Paull \& Ussler, 2008; Peckmann \& Thiel, 2004; Stadnitskaia et al., 2008). Different carbonate phases (calcite, aragonite and dolomite) will precipitate depending on the geochemical conditions (Greinert et al., 2001; Magalhães et al., 2012). For example, aragonite is favoured over calcite in seawater-ventilated environments with high sulphate concentrations that inhibit the effect of the hydrated Mg ions on the calcite structure (Greinert et al., 2001; Magalhães et al., 2012). This likely occurs when methane seepage is vigorous and reaches the sediment-seawater interface. On the other hand, $\mathrm{Mg}$ calcite and dolomite will more likely precipitate where sulphate concentrations are low or sulphide concentrations are high; either deeper in the subsurface or in semi-closed systems (Aloisi et al., 2002; Greinert et al., 2001; Haas, Peckmann, Elvert, Sahling, \& Bohrmann, 2010; Lu et al., 2018; Magalhães et al., 2012; Meister et al., 2007; Naehr et al., 2007; Niemann et al., 2006; Stadnitskaia et al., 2008).

The lipid biomarker inventory of Alpha Mound confirms that AOM locally influenced the sediments, resulting in the precipitation of abundant diagenetic carbonates and semi-lithification. The authigenic minerals observed at the SLZ in core MD13-3443G consist of high-Mg calcite, $\mathrm{Ca}$-excess dolomite and minor amounts of aragonite (Figure 3a-c). Although secondary aragonite needles have been observed within pores between the coral fragments in the SLZ (Figure 3a), aragonite occurs primarily in the form of bioskeletal CWC (Figure 2). Based on relative weight percentages and the fact that precipitation occurred only locally within cavities, it is unlikely that authigenic aragonite was a major constituent of the authigenic carbonate phases induced by AOM. On the other hand, high-Mg calcite is pervasively present as numerous small $(<5 \mu \mathrm{m})$ rhomboids within the carbonate fragments in the SLZ (Figure $3 \mathrm{~b}$ ) and is therefore a major mineral constituent. High-Mg calcite is exclusively present in the SLZ, and it likely acts as the major lithifying agent making up the brecciated fragments. This observation suggests that methane seepage in Alpha Mound was diffusive and AOM occurred in the deeper subsurface (Niemann et al., 2006; Stadnitskaia et al., 2008). This interpretation aligns well with the observation of ANME-1 predominance, which has been associated with a similar deeper and reducing setting (cf. Haas et al., 2010; Timmers, Widjaja-Greefkes, Ramiro-Garcia, Plugge, \& Stams, 2015).

Contrary to high-Mg calcite, it is questionable if the Ca-excess dolomite that precipitated in the SLZ can be attributed to AOM as well, despite its common occurrence in AOM settings. Calciumexcess dolomite occurs at other depths in Alpha Mound as well (this is in contrast to high-Mg calcite, which is exclusively present at the SLZ) and has similar petrographic characteristics independent of depth. Furthermore, petrographic evidence indicates that Ca-excess dolomite crystals (Figure $3 c$,d) have overprinted the initial brecciated fragments (Figure $3 e$ ) and formed at a later stage. Additionally, no biomarkers characteristic for AOM have been found in Ca-excess dolomite-rich layers (from 150 to $360 \mathrm{~cm}$ depth). However, elevated DAGE contents (167 and $265 \mathrm{~cm}$ depths; Figure 5) points to a link with organoclastic sulphate reduction (see Grossi et al., 2015). Evidence for pronounced organoclastic sulphate reduction has been observed in Alpha Mound sediments before (Rejas et al., 2015; Templer et al., 2011; Wehrmann et al., 2011), rendering it likely that this process plays a role in Ca-excess dolomite formation due to an increase of alkalinity induced by this process (Wehrmann, Titschack, Böttcher, \& Ferdelman, 2015). 
Another diagenetic feature of Alpha Mound is the dissolution of coral skeletons (Foubert et al., 2008; Pirlet et al., 2012; Wehrmann et al., 2011), which, based on the petrography, appears to be closely associated with the former presence of the SMTZ (Figure 3f). The dissolution of corals in the sediment within and particularly above the SMTZ was likely driven by the upward diffusion and subsequent interaction of AOM-derived hydrogen sulphide with the carbonate system, driving carbonate undersaturation and coral dissolution (Wehrmann et al., 2011). An additional mechanism could include organoclastic sulphate reduction during earlier stages of mound formation, which can lower the $\mathrm{pH}$ depending on substrates and iron speciation (Coleman et al., 1985; Coleman \& Raiswell, 1995; Soetaert, Hofmann, Middelburg, Meysman, \& Greenwood, 2007). This process has been proposed as a main driver of coral dissolution in Challenger Mound in the Porcupine Seabight (Wehrmann et al., 2015).

\section{3 | Exhumation and superimposed geochemical signals}

Interestingly, irregular and circular features (Figure 3g,h) observed in the sediment of the SLZ indicate that the sediment underwent (bio-) erosive processes at the sediment-water interface. This shows that the SLZ was exhumed at some point and reached the sediment-seawater interface after initial semi-lithification. A similar observation was made by Van der Land et al. (2010), who observed erosional features in a lithified interval that was initially formed in the subsurface and was later exhumed.

Exhumation of the SLZ may explain why aragonite is observed in addition to high-Mg calcite. Perhaps, high-Mg calcite cement formed at an earlier stage in the subsurface, when methane seepage intensity was relatively low and seepage was diffusive. During a later phase that coincided with exhumation, the methane flow increased, resulting in $\mathrm{AOM}$ at the sediment-seawater interface and leading to local aragonite precipitation in the cavities of coral skeletal clasts. Alternatively, aragonite precipitation may have resulted from abiotic processes when the SLZ was exhumed. Abiotic formation of authigenic aragonite at the sediment-seawater interface can occur when ions from oversaturated seawater diffuse into the pore waters during prolonged exposure during exhumation (Allouc, 1990; Christ, Immenhauser, Wood, Darwich, \& Niedermayr, 2015; Noé, Titschack, Freiwald, \& Dullo, 2006; Swart, 2015).

Collectively, the obtained biomarker data demonstrate the presence of ANMEs and Thaumarchaeota. Signals indicating different geochemical processes are also apparent from the mineralogy (co-occurrence of aragonite, high-Mg calcite and Ca-excess dolomite). The presence of lipids and mineral phases of different origins is caused by changes in environmental conditions over time. Variations in environmental conditions in Alpha Mound are likely the result of changes in sedimentation (e.g. mound aggradation and exhumation) and/or fluid (or gas) circulation patterns, which in turn affects the spatial and temporal distribution of biogeochemical processes such as AOM and organoclastic sulphate reduction.
Fluctuation of methane flux at Alpha Mound has already been discussed in earlier studies (Pirlet et al., 2012; Wehrmann et al., 2011). Increasing methane flux is commonly accompanied by brecciation of semi-lithified sediment (Figure 3e). Brecciation is a common phenomenon at seeps (Bohrmann et al., 1998; Greinert et al., 2001; Hovland, Talbot, Qvale, Olaussen, \& Aasberg, 1987; Paull \& Ussler, 2008; Peckmann \& Thiel, 2004) and has been interpreted to result from different processes including tectonic and slump processes (Greinert etal., 2001), pressure build-up below lithified intervals due to accumulation of methane (Hovland et al., 1987) or from the release of buoyant gas hydrates in the shallow subsurface (Greinert et al., 2001; Suess et al., 2001). Since no slumping has been observed in the Alpha Mound area, and conditions inside the mound are not within the stability zone for gas hydrate formation, brecciation likely occurred via accumulation of methane below (semi-)lithified intervals. Increase in methane flux may have led to pressurizing below the SLZ, causing fracturing.

No methane gas was measured in core MD13-3443G (L. Wehrmann, unpublished results); however, methane concentrations up to 2.0 mM were detected in Alpha Mound (Maignien et al., 2011; Wehrmann et al., 2011). This suggests that methane seepage continues today. Based on the coral ages of this study, AOM-induced semi-lithification of the sediment between 506 and $478 \mathrm{~cm}$ depth occurred prior to $320 \mathrm{ka}$. Afterwards, the SMTZ has most likely moved downward below a depth of $6 \mathrm{~m}$.

Interestingly, the presence of superimposed geochemical signals has already been suggested after measurement of $\delta^{13} \mathrm{C}_{\text {carbonate }}$ values of Alpha Mound bulk sediments (Pirlet et al., 2012), which yielded values between $-21.5 \%$ and $-1.9 \%$. Pirlet et al. (2012) suggested that these values might reflect a combination of dissolved inorganic carbon (DIC) produced during $\mathrm{AOM}$ and organoclastic sulphate reduction, indicating mixing of DIC derived from different sources. Our new biomarker data agree with the inference of Pirlet et al. (2012) that AOM played a prominent role in mound biogeochemistry in the past. Our study also confirms that lipid biomarkers are commonly more suitable to discriminate between early diagenetic processes than stable isotopes of carbonate fractions, although a combination of organic and inorganic geochemical approaches will always be advantageous.

\subsection{The role of anaerobic oxidation of methane in cold-water coral mounds}

We posit that CWC growth re-initiated at the exhumed surface (Figure 2) where the semi-lithified sediment acted as substrate for CWC larval settlement. Initially, CWC growth began with solitary corals and was followed by framework-building corals (Figure 2). It is possible that solitary corals tolerate more stressful environments and are able to colonize before conditions ameliorate sufficiently for framework-building corals. The role of hardgrounds as a potential substrate for larval settlement has already been suggested (Goedert \& Peckmann, 2005; Rincón-Tomás et al., 2019; Rueda et al., 2016; 
Rüggeberg \& Foubert, 2019; Van Rooij et al., 2011). The availability of hard substrate is believed to be an important criterion for CWC growth, given that they are subjected to high current regimes (Freiwald, 2002; Noé et al., 2006).

A distinction between semi-lithified intervals formed within the subsurface and hardgrounds formed at the seafloor is possible. The latter are massive slabs on the surface of mounds (De Mol, 2012; Noé et al., 2006) typified by current-induced sedimentary structures, a non-luminescing matrix indicating oxic pore fluids and a normal marine isotopic signature lacking ${ }^{13} \mathrm{C}$-depletion typical of $\mathrm{AOM}$ (Noé et al., 2006). Besides seafloor hardgrounds, semi-lithified layers that form within a mound may play an instrumental role in stabilizing the mound structure (Pirlet et al., 2012). Semi-lithified layers are reported from most CWC mounds, but their formation is only poorly studied. We are now able to demonstrate that the formation of one of these mounds-Alpha Mound-was affected by AOM activity. The significance of AOM-induced semi-lithification in CWC mounds may, thus, have been underestimated in former studies. In this study, we show that lipid biomarker analysis can be used to locate zones of past AOM activity in Alpha Mound, identifying semi-lithified horizons that formed as a result of AOM. Given that geochemical signatures such as $\delta^{13} C_{\text {carbonate }}$ values of bulk sediments often reflect the mixing of different processes, our findings highlight that biomarker analyses represent an excellent tool to help decipher the formation mechanisms of semi-lithified horizons in cold-water coral mounds and other sub-seafloor environments.

\section{6 | CONCLUSIONS}

This study demonstrates that methane seepage in cold-water coral (CWC) mounds can be traced by a combined study of lipid biomarkers and petrography. Various microbial processes affected the sediments of Alpha Mound from the El Arraiche mud volcano field in the Gulf of Cadiz. The anaerobic oxidation of methane (AOM) led to precipitation of high-Mg calcite cement and consequent lithification of the sediment, whilst organoclastic sulphate reduction probably favoured the precipitation of $\mathrm{Ca}$-excess dolomite. Lipid biomarkers confirm former AOM activity in a high-Mg calcite-rich semi-lithified zone, including increased abundance of glycerol dibiphytanyl glycerol tetraethers (GDGTs) and ${ }^{13} \mathrm{C}$-depleted ether-cleaved biphytanes. The semi-lithified zone most likely represents a fossil sulphate-methane transition zone (SMTZ), where AOM was performed by archaea of the ANME-1 cluster during times of diffusive seepage. Petrographic analysis revealed that the semi-lithified zone was exhumed after seepage ceased and acted as substrate for CWC larval settlement. In addition to substrate formation, AOM-induced semilithified layers probably enhanced mound integrity.

Overall, subsurface microbial processes such as AOM can play a significant role in changing the fabric of mounds by inducing (semi-) lithification of the sediment. This study reveals that sedimentary patterns (e.g. exhumation and aggradation) and/or fluctuations of the SMTZ can result in multiple, superimposed geochemical signatures.
Lipid biomarkers are powerful tools for disentangling different early diagenetic processes induced by microbial metabolisms. Such an approach is very likely to aid the endeavour of reconstructing the formation of ancient carbonate mounds.

\section{ACKNOWLEDGMENTS}

The authors would like to dedicate this manuscript to Prof. Dr. JeanPierre Henriet, a key figure in mound research along continental margins and initiator of the EuroFLEETS GATEWAYS project. This study has been funded through the SNF project (Swiss National Science Foundation) 4D-Diagenesis@Mound (SNF project number 200021_149247). We acknowledge the shiptime provided by IPEV on R/V Marion Dufresne within the framework of the EuroFLEETS GATEWAYS project (grant agreement 228344). The technical crew and scientific staff of the R/V Marion Dufresne EuroFLEETS GATEWAYS expedition are thanked for the wonderful time onboard and the stimulating scientific discussions. The authors would like to thank P. Dietzsche, A. Salzmann and C. Neururer for all the help during sample, thin section and SEM preparation. We thank Beatrix Bethke (Vienna) for assistance with lipid biomarker extraction procedures, Sabine Beckmann (Hamburg) for ether cleavage of biphytanes and measuring GDGTs, as well as Anne-Marie Wefing (Heidelberg) for helping with uranium-series measurements. We also thank the anonymous reviewers for insightful comments that helped improve the manuscript.

\section{ORCID}

Eline Juliette Feenstra (iD https://orcid.org/0000-0002-0901-1174 Jörn Peckmann (iD https://orcid.org/0000-0002-8572-0060

\section{REFERENCES}

Addamo, A. M., Vertino, A., Stolarski, J., García-Jiménez, R., Taviani, M., \& Machordom, A. (2016). Merging scleractinian genera: the overwhelming genetic similarity between solitary Desmophyllum and colonial Lophelia. BMC Evolutionary Biology., 16(1).

Allouc, J. (1990). Quaternary crusts on slopes of the Mediterranean Sea: A tentative explanation for their genesis. Marine Geology, 94, 205238. https://doi.org/10.1016/0025-3227(90)90070-Z

Aloisi, G., Bouloubassi, I., Heijs, S. K., Pancost, R. D., Pierre, C., Sinninghe Damsté, J. S., ... Rouchy, J.- M. (2002). $\mathrm{CH}_{4}$-consuming microorganisms and the formation of carbonate crusts at cold seeps. Earth and Planetary Science Letters, 203, 195-203. https://doi. org/10.1016/S0012-821X(02)00878-6

Ambar, I., Serra, N., Neves, F., \& Ferreira, T. (2008). Observations of the Mediterranean Undercurrent and eddies in the Gulf of Cadiz during 2001. Journal of Marine Systems, 71, 195-220. https://doi. org/10.1016/j.jmarsys.2007.07.003

Andersen, M. B., Stirling, C. H., Zimmermann, B., \& Halliday, A. N (2010). Precise determination of the open ocean ${ }^{234} U /{ }^{238} U$ composition. Geochemistry, Geophysics, Geosystems, 11, https://doi. org/10.1029/2010GC003318

Baumann, L. M. F., Taubner, R.-S., Bauersachs, T., Steiner, M., Schleper, C., Peckmann, J., ... Birgel, D. (2018). Intact polar lipid and core lipid inventory of the hydrothermal vent methanogens Methanocaldococcus villosus and Methanothermococcus okinawensis. Organic Geochemistry, 126, 33-42. https://doi.org/10.1016/j.orggeochem.2018.10.006

Biddle, J. F., Lipp, J. S., Lever, M. A., Lloyd, K. G., Sørensen, K. B., Anderson, R., ... Hinrichs, K.-U. (2006). Heterotrophic Archaea 
dominate sedimentary subsurface ecosystems off Peru. Proceedings of the National Academy of Sciences, 103, 3846-3851. https://doi. org/10.1073/pnas.0600035103

Birgel, D., Guido, A., Liu, X., Hinrichs, K.-U., Gier, S., \& Peckmann, J. (2014). Hypersaline conditions during deposition of the Calcare di Base revealed from archaeal di-and tetraether inventories. Organic Geochemistry, 77, 11-21. https://doi.org/10.1016/j.orgge ochem.2014.09.002

Birgel, D., \& Peckmann, J. (2008). Aerobic methanotrophy at ancient marine methane seeps: A synthesis. Organic Geochemistry, 39, 16591667. https://doi.org/10.1016/j.orggeochem.2008.01.023

Birgel, D., Thiel, V., Hinrichs, K.-U., Elvert, M., Campbell, K. A., Reitner, J., ... Peckmann, J. (2006). Lipid biomarker patterns of methane-seep microbialites from the Mesozoic convergent margin of California. Organic Geochemistry, 37, 1289-1302. https://doi.org/10.1016/j. orggeochem.2006.02.004

Blaga, C. I., Reichart, G.-J., Heiri, O., Sinninghe Damsté, J. S. (2009). Tetraether membrane lipid distributions in water-column particulate matter and sediments: A study of 47 European lakes along a northsouth transect. Journal of Paleolimnology, 41, 523-540. https://doi. org/10.1007/s10933-008-9242-2

Blumenberg, M., Seifert, R., Reitner, J., Pape, T., \& Michaelis, W. (2004). Membrane lipid patterns typify distinct anaerobic methanotrophic consortia. Proceedings of the National Academy of Sciences of the United States of America, 101, 11111-11116. https://doi.org/10.1073/ pnas.0401188101

Boetius, A., Ravenschlag, K., Schubert, C. J., Rickert, D., Widdel, F., Gieseke, A., ... Pfannkuche, O. (2000). A marine microbial consortium apparently mediating anaerobic oxidation of methane. Nature, 407, 623. https://doi.org/10.1038/35036572

Bohrmann, G., Greinert, J., Suess, E., \& Torres, M. (1998). Authigenic carbonates from the Cascadia subduction zone and their relation to gas hydrate stability. Geology, 26, 647-650. https://doi. org/10.1130/0091-7613(1998)026<0647:ACFTCS>2.3.CO;2

Cheng, H., Edwards, R. L., Hoff, J., Gallup, C. D., Richards, D. A., \& Asmerom, Y. (2000). The half-lives of uranium-234 and thorium-230. Chemical Geology, 169, 17-33. https://doi.org/10.1016/ S0009-2541(99)00157-6

Chevalier, N., Bouloubassi, I., Birgel, D., Crémière, A., Taphanel, M.H., \& Pierre, C. (2011). Authigenic carbonates at cold seeps in the Marmara Sea (Turkey): A lipid biomarker and stable carbon and oxygen isotope investigation. Marine Geology, 288, 112-121. https://doi. org/10.1016/j.margeo.2011.08.005

Christ, N., Immenhauser, A., Wood, R. A., Darwich, K., \& Niedermayr, A. (2015). Petrography and environmental controls on the formation of Phanerozoic marine carbonate hardgrounds. EarthScience Reviews, 151, 176-226. https://doi.org/10.1016/j.earsc irev.2015.10.002

Coleman, M. L., Berner, R. A., Durand, B., Meadows, P. S., Eglinton, G., Eglinton, G., ... Murchison, D. G. (1985). Geochemistry of diagenetic non-silicate minerals: Kinetic considerations. Philosophical Transactions of the Royal Society of London A: Mathematical and Physical Sciences, 315, 39-56. https://doi.org/10.1098/rsta.1985.0028

Coleman, M. L., \& Raiswell, R. (1995). Source of carbonate and origin of zonation in pyritiferous carbonate concretions; evaluation of a dynamic model. American Journal of Science, 295, 282-308. https://doi. org/10.2475/ajs.295.3.282

Cook, M. S., Keigwin, L. D., Birgel, D., \& Hinrichs, K.-U. (2011). Repeated pulses of vertical methane flux recorded in glacial sediments from the southeast Bering Sea. Paleoceanography, 26. https://doi.org/10.1029/2010PA001993.

Davies, A. J., Wisshak, M., Orr, J. C., \& Murray Roberts, J. (2008). Predicting suitable habitat for the cold-water coral Lophelia pertusa (Scleractinia). Deep Sea Research Part I: Oceanographic Research Papers, 55, 1048-1062. https://doi.org/10.1016/j.dsr.2008.04.010
De Mol, B., Van Rensbergen, P., Pillen, S., Van Herreweghe, K., Van Rooij, D., McDonnell, A., ... Henriet, J. P. (2002). Large deep-water coral banks in the Porcupine Basin, southwest of Ireland. Marine Geology, 188, 193-231. https://doi.org/10.1016/S0025-3227(02)00281-5

De Mol, L. (2012). Visual and sedimentological characterisation of cold-water coral mounds: From a single coral up to a large mound. Ghent, Belgium: Ghent University, Faculty of Sciences.

Dewey, J., Helman, M., Knott, S., Turco, E., \& Hutton, D. (1989). Kinematics of the western Mediterranean. Geological Society, London, Special Publications, 45, 265-283. https://doi.org/10.1144/GSL. SP.1989.045.01.15

Díaz-del-Río, V., Somoza, L., Martínez-Frias, J., Mata, M. D. P., Delgado Huertas, A., Hernández-Molina, F., ... Vazquez, J.-T. (2003). Vast fields of hydrocarbon-derived carbonate chimneys related to the accretionary wedge/olistostrome of the Gulf of Cadiz. Marine Geology, 195, 177-200. https://doi.org/10.1016/S0025-3227(02)00687-4

Dorschel, B., Hebbeln, D., Rüggeberg, A., Dullo, W.-C., \& Freiwald, A. (2005). Growth and erosion of a cold-water coral covered carbonate mound in the Northeast Atlantic during the Late Pleistocene and Holocene. Earth and Planetary Science Letters, 233, 33-44. https:// doi.org/10.1016/j.epsl.2005.01.035

Dullo, W.-C., Flögel, S., \& Rüggeberg, A. (2008). Cold-water coral growth in relation to the hydrography of the Celtic and Nordic European continental margin. Marine Ecology Progress Series, 371, 165-176. https://doi.org/10.3354/meps07623

Elvert, M., Hopmans, E., Treude, T., Boetius, A., \& Suess, E. (2005). Spatial variations of methanotrophic consortia at cold methane seeps: Implications from a high-resolution molecular and isotopic approach. Geobiology, 3, 195-209. https://doi. org/10.1111/j.1472-4669.2005.00051.x

Elvert, M., Suess, E., Greinert, J., \& Whiticar, M. J. (2000). Archaea mediating anaerobic methane oxidation in deep-sea sediments at cold seeps of the eastern Aleutian subduction zone. Organic Geochemistry, 31, 1175-1187. https://doi.org/10.1016/S0146-6380(00)00111-X

Elvert, M., Suess, E., \& Whiticar, M. J. (1999). Anaerobic methane oxidation associated with marine gas hydrates: Superlight $\mathrm{C}$-isotopes from saturated and unsaturated $\mathrm{C}_{20}$ and $\mathrm{C}_{25}$ irregular isoprenoids. Naturwissenschaften, 86, 295-300. https://doi.org/10.1007/s0011 40050619

Feng, D., Birgel, D., Peckmann, J., Roberts, H. H., Joye, S. B., Sassen, R., ... Chen, D. (2014). Time integrated variation of sources of fluids and seepage dynamics archived in authigenic carbonates from Gulf of Mexico Gas Hydrate Seafloor Observatory. Chemical Geology, 385, 129-139. https://doi.org/10.1016/j.chemgeo.2014.07.020

Fernández-Puga, M. C., Vázquez, J. T., Somoza, L., Díaz del Rio, V., Medialdea, T., Mata, M. P., \& León, R. (2007). Gas-related morphologies and diapirism in the Gulf of Cádiz. Geo-Marine Letters, 27, 213221. https://doi.org/10.1007/s00367-007-0076-0

Fink, H. G., Wienberg, C., De Pol-Holz, R., Wintersteller, P., \& Hebbeln, D. (2013). Cold-water coral growth in the Alboran Sea related to high productivity during the Late Pleistocene and Holocene. Marine Geology, 339, 71-82. https://doi.org/10.1016/j. margeo.2013.04.009

Foubert, A., Depreiter, D., Beck, T., Maignien, L., Pannemans, B., Frank, N., ... Henriet, J.-P. (2008). Carbonate mounds in a mud volcano province off north-west Morocco: Key to processes and controls. Marine Geology, 248, 74-96. https://doi.org/10.1016/j.margeo.2007.10.012

Foubert, A., \& Henriet, J.-P. (2009). Nature and significance of the recent carbonate mound record: the mound challenger code (Lecture Notes in Eart Sciences, Vol. 126). Berlin, Heidelberg: Springer Science \& Business Media.

Frank, N., Freiwald, A., Correa, M. L., Wienberg, C., Eisele, M., Hebbeln, D., ... Hatté, C. (2011). Northeastern Atlantic cold-water coral reefs and climate. Geology, 39, 743-746. https://doi.org/10.1130/ G31825.1 
Frank, N., Paterne, M., Ayliffe, L., van Weering, T., Henriet, J.-P., \& Blamart, D. (2004). Eastern North Atlantic deep-sea corals: Tracing upper intermediate water $\Delta^{14} \mathrm{C}$ during the Holocene. Earth and Planetary Science Letters, 219, 297-309. https://doi.org/10.1016/ S0012-821X(03)00721-0

Freiwald, A. (2002). Reef-forming cold-water corals. In G. Wefer, D. Billet, D. Hebbeln, B. B. Jørgensen, M. Schlüter \& T. C. E. V. Weering (Eds.), Ocean margin systems (pp. 365-385). Berlin, Heidelberg: Springer.

Freiwald, A., Fossa, J. H., Grehan, A., Koslow, T., \& Roberts, J. M. (2004). Cold-water coral reefs: Out of sight-no longer out of mind (Vol. 84). Cambridge, UK: UNEP-WCMC.

Goedert, J. L., \& Peckmann, J. (2005). Corals from deep-water methane-seep deposits in Paleogene strata of Western Oregon and Washington, USA. In A. Freiwald \& J. Murray Roberts (Eds.), ColdWater Corals and Ecosystems (pp. 27-40). Eds.: Freiwald, A., Murray Roberts, J., Springer Verlag, Berlin, Heidelberg, Germany.

González, F., Somoza, L., Lunar, R., Martínez-Frías, J., Rubí, J. M., Torres, T., ... Magalhães, V. (2009). Hydrocarbon-derived ferromanganese nodules in carbonate-mud mounds from the Gulf of Cadiz: Mudbreccia sediments and clasts as nucleation sites. Marine Geology, 261, 64-81. https://doi.org/10.1016/j.margeo.2008.11.005

Gràcia, E., Dañobeitia, J., Vergés, J., Bartolomé, R., \& Córdoba, D. (2003). Crustal architecture and tectonic evolution of the Gulf of Cadiz (SW Iberian margin) at the convergence of the Eurasian and African plates. Tectonics, 22, https://doi.org/10.1029/2001T C901045

Gregg, J. M., Bish, D. L., Kaczmarek, S. E., \& Machel, H. G. (2015). Mineralogy, nucleation and growth of dolomite in the laboratory and sedimentary environment: A review. Sedimentology, 62, 1749-1769. https://doi.org/10.1111/sed.12202

Greinert, J., Bohrmann, G., \& Suess, E. (2001). Gas Hydrate-associated carbonates and methane-venting at hydrate ridge: Classification, distribution, and origin of authigenic lithologies. In C. K.Paull \& W. P. Dillon (Eds.), Natural gas hydrates: Occurrence, distribution, and detection (pp. 99-113). Washington, DC: American Geophysical Union.

Grossi, V., Mollex, D., Vinçon-Laugier, A., Hakil, F., Pacton, M., \& CravoLaureau, C. (2015). Mono-and dialkyl glycerol ether lipids in anaerobic bacteria: biosynthetic insights from the mesophilic sulfate-reducer Desulfatibacillum alkenivorans PF2803T. Applied and Environmental Microbiology, 81, 3157-3168.

Haas, A., Peckmann, J., Elvert, M., Sahling, H., \& Bohrmann, G. (2010). Patterns of carbonate authigenesis at the Kouilou pockmarks on the Congo deep-sea fan. Marine Geology, 268, 129-136. https://doi. org/10.1016/j.margeo.2009.10.027

Hebbeln, D., Van Rooij, D., \& Wienberg, C. (2016). Good neighbours shaped by vigorous currents: Cold-water coral mounds and contourites in the North Atlantic. Marine Geology, 378, 171-185. https://doi. org/10.1016/j.margeo.2016.01.014

Henriet, J. P., De Mol, B., Pillen, S., Vanneste, M., Van Rooij, D., Versteeg, W., ... Chachkine, P. (1998). Gas hydrate crystals may help build reefs. Nature, 391, 648-649. https://doi.org/10.1038/35530

Hensen, C., Nuzzo, M., Hornibrook, E., Pinheiro, L. M., Bock, B., Magalhães, V. H., \& Brückmann, W. (2007). Sources of mud volcano fluids in the Gulf of Cadiz-indications for hydrothermal imprint. Geochimica Et Cosmochimica Acta, 71, 1232-1248. https://doi. org/10.1016/j.gca.2006.11.022

Hernández-Molina, F. J., Llave, E., Stow, D. A. V., García, M., Somoza, L., Vázquez, J. T., ... Gardner, J. (2006). The contourite depositional system of the Gulf of Cádiz: A sedimentary model related to the bottom current activity of the Mediterranean outflow water and its interaction with the continental margin. Deep Sea Research Part II: Topical Studies in Oceanography, 53, 1420-1463. https://doi.org/10.1016/j. dsr2.2006.04.016

Hernández-Molina, F. J., Serra, N., Stow, D. A. V., Llave, E., Ercilla, G., \& Van Rooij, D. (2011). Along-slope oceanographic processes and sedimentary products around the Iberian margin. Geo-Marine Letters, 31, 315-341. https://doi.org/10.1007/s00367-011-0242-2

Hinrichs, K.-U., Hayes, J. M., Sylva, S. P., Brewer, P. G., \& DeLong, E. F. (1999). Methane-consuming archaebacteria in marine sediments. Nature, 398, 802. https://doi.org/10.1038/19751

Hinrichs, K.-U., Summons, R. E., Orphan, V., Sylva, S. P., \& Hayes, J. M. (2000). Molecular and isotopic analysis of anaerobic methane-oxidizing communities in marine sediments. Organic Geochemistry, 31, 1685-1701. https://doi.org/10.1016/S0146-6380(00)00106-6

Hoefs, M., Schouten, S., De Leeuw, J., King, L. L., Wakeham, S. G., \& Sinninghe Damsté, J. S. (1997). Ether lipids of planktonic archaea in the marine water column. Applied and Environmental Microbiology, 63 , 3090-3095.

Hovland, M. (1990). Do carbonate reefs form due to fluid seepage? Terra Nova, 2, 8-18. https://doi.org/10.1111/j.1365-3121.1990.tb000 31.x

Hovland, M., Jensen, S., \& Indreiten, T. (2012). Unit pockmarks associated with Lophelia coral reefs off mid-Norway: More evidence of control by 'fertilizing'bottom currents. Geo-Marine Letters, 32, 545554. https://doi.org/10.1007/s00367-012-0284-0

Hovland, M., Mortensen, P. B., Brattegard, T., Strass, P., \& Rokengen, K. (1998). Ahermatypic coral banks off mid-Norway; evidence for a link with seepage of light hydrocarbons. Palaios, 13, 189-200. https://doi. org $/ 10.2307 / 3515489$

Hovland, M., Talbot, M. R., Qvale, H., Olaussen, S., \& Aasberg, L. (1987). Methane-related carbonate cements in pockmarks of the North Sea. Journal of Sedimentary Research, 57, 881-892.

Hovland, M., \& Thomsen, E. (1997). Cold-water corals-are they hydrocarbon seep related? Marine Geology, 137, 159-164. https://doi org/10.1016/S0025-3227(96)00086-2

Huvenne, V. A. I., De Mol, B., \& Henriet, J. P. (2003). A 3D seismic study of the morphology and spatial distribution of buried coral banks in the Porcupine Basin, SW of Ireland. Marine Geology, 198, 5-25. https://doi.org/10.1016/S0025-3227(03)00092-6

Ingalls, A. E., Shah, S. R., Hansman, R. L., Aluwihare, L. I., Santos, G. M., Druffel, E. R. M., \& Pearson, A. (2006). Quantifying archaeal community autotrophy in the mesopelagic ocean using natural radiocarbon. Proceedings of the National Academy of Sciences, 103, 6442. https://doi.org/10.1073/pnas.0510157103

Ivanov, M., Akhmetzhanov, A., \& Akhmanov, G. (2000). Multidisciplinary study of geological processes on the North East Atlantic and Western Mediterranean Margins. loc. Tech. S, 56.

Knittel, K., Lösekann, T., Boetius, A., Kort, R., \& Amann, R. (2005). Diversity and distribution of methanotrophic archaea at cold seeps. Applied and Environmental Microbiology, 71, 467-479. https://doi. org/10.1128/AEM.71.1.467-479.2005

Koga, Y., Nishihara, M., Morii, H., \& Akagawa-Matsushita, M. (1993). Ether polar lipids of methanogenic bacteria: Structures, comparative aspects, and biosyntheses. Microbiological Reviews, 57, 164-182.

Krüger, M., Meyerdierks, A., Glöckner, F. O., Amann, R., Widdel, F., Kube, M., ... Shima, S. (2003). A conspicuous nickel protein in microbial mats that oxidize methane anaerobically. Nature, 426, 878-881. https:// doi.org/10.1038/nature02207

Lipp, J. S., Morono, Y., Inagaki, F., \& Hinrichs, K.-U. (2008). Significant contribution of Archaea to extant biomass in marine subsurface sediments. Nature, 454, 991. https://doi.org/10.1038/nature07174

Lu, Y., Sun, X., Xu, H., Konishi, H., Lin, Z., Xu, L., ... Peckmann, J. (2018). Formation of dolomite catalyzed by sulfate-driven anaerobic oxidation of methane: Mineralogical and geochemical evidence from the northern South China Sea. American Mineralogist, 103, 720-734. https://doi.org/10.2138/am-2018-6226

Lumsden, D. N. (1979). Discrepancy between thin-section and X-ray estimates of dolomite in limestone. Journal of Sedimentary Research, 49, 429-435. 
Machín, F., Hernández-Guerra, A., \& Pelegrí, J. L. (2006). Mass fluxes in the Canary Basin. Progress in Oceanography, 70, 416-447. https://doi. org/10.1016/j.pocean.2006.03.019

Machín, F., Pelegrí, J. L., Marrero-Díaz, A., Laiz, I., \& Ratsimandresy, A. (2006). Near-surface circulation in the southern Gulf of Cádiz. Deep Sea Research Part II: Topical Studies in Oceanography, 53, 1161-1181. https://doi.org/10.1016/j.dsr2.2006.04.001

Magalhães, V. H., Pinheiro, L. M., Ivanov, M. K., Kozlova, E., Blinova, V., Kolganova, J., ... Somoza, L. (2012). Formation processes of methane-derived authigenic carbonates from the Gulf of Cadiz. Sedimentary Geology, 243-244, 155-168. https://doi.org/10.1016/j. sedgeo.2011.10.013

Maignien, L., Depreiter, D., Foubert, A., Reveillaud, J., De Mol, L., Boeckx, P., ... Boon, N. (2011). Anaerobic oxidation of methane in a cold-water coral carbonate mound from the Gulf of Cadiz. International Journal of Earth Sciences, 100, 1413-1422. https://doi.org/10.1007/ s00531-010-0528-z

Maldonado, A., Somoza, L., \& Pallarés, L. (1999). The Betic orogen and the Iberian-African boundary in the Gulf of Cadiz: Geological evolution (central North Atlantic). Marine Geology, 155, 9-43. https://doi. org/10.1016/S0025-3227(98)00139-X

Margreth, S., Gennari, G., Rüggeberg, A., Comas, M. C., Pinheiro, L., \& Spezzaferri, S. (2011). Growth and demise of cold-water coral ecosystems on mud volcanoes in the West Alboran Sea: The messages from the planktonic and benthic foraminifera. Marine Geology, 282, 26-39. https://doi.org/10.1016/j.margeo.2011.02.006

Medialdea, T., Somoza, L., Pinheiro, L. M., Fernández-Puga, M. C., Vázquez, J. T., León, R., ... Vegas, R. (2009). Tectonics and mud volcano development in the Gulf of Cádiz. Marine Geology, 261, 48-63. https://doi.org/10.1016/j.margeo.2008.10.007

Medialdea, T., Vegas, R., Somoza, L., Vázquez, J. T., Maldonado, A., Díaz-del-Río, V., ... Fernández-Puga, M. C. (2004). Structure and evolution of the "Olistostrome" complex of the Gibraltar Arc in the Gulf of Cádiz (eastern Central Atlantic): Evidence from two long seismic cross-sections. Marine Geology, 209, 173-198. https://doi. org/10.1016/j.margeo.2004.05.029

Meister, P., Mckenzie, J. A., Vasconcelos, C., Bernasconi, S., Frank, M., Gutjahr, M., \& Schrag, D. P. (2007). Dolomite formation in the dynamic deep biosphere: Results from the Peru Margin. Sedimentology, 54, 1007-1032. https://doi.org/10.1111/j.1365-3091.2007.00870.x

Michaelis, W., Seifert, R., Nauhaus, K., Treude, T., Thiel, V., Blumenberg, M., ... Gulin, M. B. (2002). Microbial reefs in the Black Sea fueled by anaerobic oxidation of methane. Science, 297, 1013. https://doi. org/10.1126/science.1072502

Naehr, T. H., Eichhubl, P., Orphan, V. J., Hovland, M., Paull, C. K., Ussler III, W., ... Greene, H. G. (2007). Authigenic carbonate formation at hydrocarbon seeps in continental margin sediments: A comparative study. Deep Sea Research Part II: Topical Studies in Oceanography, 54, 1268-1291.

Niemann, H., Duarte, J., Hensen, C., Omoregie, E., Magalhães, V. H., Elvert, M., ... Boetius, A. (2006). Microbial methane turnover at mud volcanoes of the Gulf of Cadiz. Geochimica et Cosmochimica Acta, 70, 5336-5355. https://doi.org/10.1016/j.gca.2006.08.010

Niemann, H., \& Elvert, M. (2008). Diagnostic lipid biomarker and stable carbon isotope signatures of microbial communities mediating the anaerobic oxidation of methane with sulphate. Organic Geochemistry, 39, 1668-1677. https://doi.org/10.1016/j.orgge ochem.2007.11.003

Noé, S., Titschack, J., Freiwald, A., \& Dullo, W.-C. (2006). From sediment to rock: Diagenetic processes of hardground formation in deep-water carbonate mounds of the NE Atlantic. Facies, 52, 183-208. https ://doi.org/10.1007/s10347-005-0037-x

Orphan, V. J., Hinrichs, K.-U., Ussler, W., Paull, C. K., Taylor, L., Sylva, S. P., ... DeLong, E. F. (2001). Comparative analysis of methane-oxidizing archaea and sulfate-reducing bacteria in anoxic marine sediments.
Applied and Environmental Microbiology, 67, 1922-1934. https://doi. org/10.1128/AEM.67.4.1922-1934.2001

Orphan, V. J., House, C. H., Hinrichs, K.-U., McKeegan, K. D., \& DeLong, E. F. (2001). Methane-consuming archaea revealed by directly coupled isotopic and phylogenetic analysis. Science, 293, 484-487. https://doi.org/10.1126/science.1061338

Pancost, R. D., Bouloubassi, I., Aloisi, G., Sinninghe Damsté, J. S., Party, S. S., \& Shipboard Scientific Party, M. (2001). Three series of non-isoprenoidal dialkyl glycerol diethers in cold-seep carbonate crusts. Organic Geochemistry, 32, 695-707. https://doi.org/10.1016/ S0146-6380(01)00015-8

Pancost, R. D., Coleman, J. M., Love, G. D., Chatzi, A., Bouloubassi, I., \& Snape, C. E. (2008). Kerogen-bound glycerol dialkyl tetraether lipids released by hydropyrolysis of marine sediments: A bias against incorporation of sedimentary organisms? Organic Geochemistry, 39, 1359-1371. https://doi.org/10.1016/j.orgge ochem.2008.05.002

Pancost, R. D., Hopmans, E. C., \& Sinninghe Damsté, J. S. (2001). Archaeal lipids in Mediterranean cold seeps: Molecular proxies for anaerobic methane oxidation. Geochimica Et Cosmochimica Acta, 65, 1611-1627. https://doi.org/10.1016/S0016-7037(00)00562-7

Pape, T., Blumenberg, M., Seifert, R., Egorov, V. N., Gulin, S. B., \& Michaelis, W. (2005). Lipid geochemistry of methane-seep-related Black Sea carbonates. Palaeogeography, Palaeoclimatology, Palaeoecology, 227, 31-47. https://doi.org/10.1016/j.palaeo.2005.04.030

Paull, C. K., \& Ussler III, W. (2008). Re-evaluating the significance of seafloor accumulations of methane-derived carbonates: seepage or erosion indicators. Paper presented at the Proceedings of the 6th International Conference on Gas Hydrates (ICGH 2008), Vancouver, British Columbia, Canada, July.

Pearson, A., Hurley, S. J., Walter, S. R. S., Kusch, S., Lichtin, S., \& Zhang, Y. G. (2016). Stable carbon isotope ratios of intact GDGTs indicate heterogeneous sources to marine sediments. Geochimica et Cosmochimica Acta, 181, 18-35. https://doi.org/10.1016/j.gca.2016.02.034

Peckmann, J., Birgel, D., \& Kiel, S. (2009). Molecular fossils reveal fluid composition and flow intensity at a Cretaceous seep. Geology, 37, 847-850. https://doi.org/10.1130/G25658A.1

Peckmann, J., Reimer, A., Luth, U., Luth, C., Hansen, B., Heinicke, C., ... Reitner, J. (2001). Methane-derived carbonates and authigenic pyrite from the northwestern Black Sea. Marine Geology, 177, 129-150. https://doi.org/10.1016/S0025-3227(01)00128-1

Peckmann, J., \& Thiel, V. (2004). Carbon cycling at ancient methaneseeps. Chemical Geology, 205, 443-467. https://doi.org/10.1016/j. chemgeo.2003.12.025

Peckmann, J., Thiel, V., Michaelis, W., Clari, P., Gaillard, C., Martire, L., \& Reitner, J. (1999). Cold seep deposits of Beauvoisin (Oxfordian; southeastern France) and Marmorito (Miocene; northern Italy): Microbially induced authigenic carbonates. International Journal of Earth Sciences, 88, 60-75. https://doi.org/10.1007/s0053 10050246

Pelegrí, J. L., Marrero-Díaz, A., Ratsimandresy, A., Antoranz, A., CisnerosAguirre, J., Gordo, C., ... Sangrà, P. (2005). Hydrographic cruises off northwest Africa: The Canary Current and the Cape Ghir region. Journal of Marine Systems, 54, 39-63. https://doi.org/10.1016/j.jmars ys.2004.07.001

Pinheiro, L. M., Ivanov, M. K., Sautkin, A., Akhmanov, G., Magalhães, V. H., Volkonskaya, A., ... Cunha, M. R. (2003). Mud volcanism in the Gulf of Cadiz: Results from the TTR-10 cruise. Marine Geology, 195, 131-151. https://doi.org/10.1016/S0025-3227(02)00685-0

Pirlet, H., Wehrmann, L. M., Foubert, A., Brunner, B., Blamart, D., De Mol, L., ... Henriet, J.-P. (2012). Unique authigenic mineral assemblages reveal different diagenetic histories in two neighbouring cold-water coral mounds on Pen Duick Escarpment, Gulf of Cadiz. Sedimentology, 59, 578-604. https://doi.org/10.1111/j.13653091.2011.01267.x 
Reeburgh, W. S. (1980). Anaerobic methane oxidation: Rate depth distributions in Skan Bay sediments. Earth and Planetary Science Letters, 47, 345-352. https://doi.org/10.1016/0012-821X(80)90021-7

Rejas, M., Taberner, C., Pueyo, J. J., Giralt, S., Mata, M., de Gibert, J. M., \& del Río, V. D. (2015). Origin of carbonate concretions from mud mounds in the Gulf of Cadiz (SW Iberian Peninsula). Boletín Geológico y Minero, 126, 553-574.

Richardson, P., Bower, A., \& Zenk, W. (2000). A census of Meddies tracked by floats. Progress in Oceanography, 45, 209-250. https://doi. org/10.1016/S0079-6611(99)00053-1

Rincón-Tomás, B., Duda, J. P., Somoza, L., González, F. J., Schneider, D., Medialdea, T., ... Reitner, J. (2019). Cold-water corals and hydrocarbon-rich seepage in Pompeia Province (Gulf of Cádiz) - Living on the edge. Biogeosciences, 16, 1607-1627. https://doi.org/10.5194/ bg-16-1607-2019

Roberts, J. M., Wheeler, A. J., \& Freiwald, A. (2006). Reefs of the deep: The biology and geology of cold-water coral ecosystems. Science, 312, 543. https://doi.org/10.1126/science.1119861

Roberts, J. M., Wheeler, A., Freiwald, A., \& Cairns, S. (2009). Cold-water corals: The biology and geology of deep-sea coral habitats. Cambridge, UK: Cambridge University Press.

Rossel, P. E., Lipp, J. S., Fredricks, H. F., Arnds, J., Boetius, A., Elvert, M., \& Hinrichs, K.-U. (2008). Intact polar lipids of anaerobic methanotrophic archaea and associated bacteria. Organic Geochemistry, 39, 992-999. https://doi.org/10.1016/j.orggeochem.2008.02.021

Rueda, J. L., González-García, E., Krutzky, C., López-Rodriguez, F. J., Bruque, G., López-González, N., ... Díaz-del-Río, V. (2016). From chemosynthesis-based communities to cold-water corals: Vulnerable deep-sea habitats of the Gulf of Cádiz. Marine Biodiversity, 46, 473482. https://doi.org/10.1007/s12526-015-0366-0

Rüggeberg, A., Fietzke, J., Liebetrau, V., Eisenhauer, A., Dullo, W.-C., \& Freiwald, A. (2008). Stable strontium isotopes $\left(\delta^{88} / 86 \mathrm{Sr}\right)$ in cold-water corals-A new proxy for reconstruction of intermediate ocean water temperatures. Earth and Planetary Science Letters, 269, 570575. https://doi.org/10.1016/j.epsl.2008.03.002

Rüggeberg, A., \& Foubert, A. (2019). Drop chapter: Cold-water corals and mud volcanoes: Life on a dynamic substrate. In C. Orejas, \& C. Jiménez (Eds.), Mediterranean cold-water corals: Past, present and future (1st ed., Vol. 9, pp. 265-269). Berlin, Heidelberg: Springer International Publishing.

Schouten, S., Hoefs, M. J., Koopmans, M. P., Bosch, H.-J., \& Sinninghe Damsté, J. S. (1998). Structural characterization, occurrence and fate of archaeal ether-bound acyclic and cyclic biphytanes and corresponding diols in sediments. Organic Geochemistry, 29, 1305-1319. https://doi.org/10.1016/S0146-6380(98)00131-4

Schouten, S., Hopmans, E. C., \& Sinninghe Damsté, J. S. (2013). The organic geochemistry of glycerol dialkyl glycerol tetraether lipids: A review. Organic Geochemistry, 54, 19-61. https://doi.org/10.1016/j. orggeochem.2012.09.006

Sinninghe Damsté, J. S., Schouten, S., Hopmans, E. C., van Duin, A. C., \& Geenevasen, J. A. (2002). Crenarchaeol the characteristic core glycerol dibiphytanyl glycerol tetraether membrane lipid of cosmopolitan pelagic crenarchaeota. Journal of Lipid Research, 43, 1641-1651. https://doi.org/10.1194/jlr.M200148-JLR200

Soetaert, K., Hofmann, A. F., Middelburg, J. J., Meysman, F. J., \& Greenwood, J. (2007). Reprint of "The effect of biogeochemical processes on pH". Marine Chemistry, 106, 380-401. https://doi. org/10.1016/j.marchem.2007.06.008

Somoza, L., Ivanov, M., Pinheiro, L., Maestro, A., Lowrie, A., Vazquez, J., ... Fernandez-Puga, M. (2001). Structural and tectonic control of fluid seeps and mud volcanoes in the Gulf of Cádiz. Geological Processes on Deep-Water European Margins. IOC Worksh Rep, 175, 41-42.

Stadnitskaia, A., Ivanov, M. K., Blinova, V., Kreulen, R., \& van Weering, T. C. E. (2006). Molecular and carbon isotopic variability of hydrocarbon gases from mud volcanoes in the Gulf of Cadiz, NE Atlantic. Marine and Petroleum Geology, 23, 281-296. https://doi.org/10.1016/j marpetgeo.2005.11.001

Stadnitskaia, A., Nadezhkin, D., Abbas, B., Blinova, V., Ivanov, M. K., \& Sinninghe Damsté, J. S. (2008). Carbonate formation by anaerobic oxidation of methane: Evidence from lipid biomarker and fossil 16S rDNA. Geochimica et Cosmochimica Acta, 72, 1824-1836. https://doi. org/10.1016/j.gca.2008.01.020

Stalder, C., El Kateb, A., Vertino, A., Rüggeberg, A., Camozzi, O. Pirkenseer, C. M., ... Spezzaferri, S. (2018). Large-scale paleoceanographic variations in the western Mediterranean Sea during the last 34,000 years: From enhanced cold-water coral growth to declining mounds. Marine Micropaleontology, 143, 46-62. https://doi. org/10.1016/j.marmicro.2018.07.007

Stalder, C., Vertino, A., Rosso, A., Rüggeberg, A., Pirkenseer, C., Spangenberg, J. E., ... Hajdas, I. (2015). Microfossils, a key to unravel cold-water carbonate mound evolution through time: Evidence from the Eastern Alboran Sea. PLoS ONE, 10, e0140223. https://doi. org/10.1371/journal.pone.0140223

Suess, E., Torres, M. E., Bohrmann, G., Collier, R. W., Rickert, D., Goldfinger, C. ... Elver, M. (2001). Sea floor methane hydrates at Hydrate Ridge, Cascadia margin. In C. K. Paull, \& W. P. Dillon (Eds.), Natural gas hydrates: Occurrence, distribution, and detection (pp. 8798). Washington, DC: American Geophysical Union.

Swart, P. K. (2015). The geochemistry of carbonate diagenesis: The past, present and future. Sedimentology, 62, 1233-1304. https://doi org/10.1111/sed.12205

Templer, S. P., Wehrmann, L. M., Zhang, Y., Vasconcelos, C., \& McKenzie, J. A. (2011). Microbial community composition and biogeochemical processes in cold-water coral carbonate mounds in the Gulf of Cadiz, on the Moroccan margin. Marine Geology, 282, 138-148. https://doi org/10.1016/j.margeo.2010.10.020

Teske, A., Hinrichs, K.-U., Edgcomb, V., de Vera Gomez, A., Kysela, D., Sylva, S. P., ... Jannasch, H. W. (2002). Microbial diversity of hydrothermal sediments in the Guaymas Basin: Evidence for anaerobic methanotrophic communities. Applied and Environmental Microbiology, 68, 1994-2007. https://doi.org/10.1128/ AEM.68.4.1994-2007.2002

Thiel, V., Peckmann, J., Richnow, H. H., Luth, U., Reitner, J., \& Michaelis, W. (2001). Molecular signals for anaerobic methane oxidation in Black Sea seep carbonates and a microbial mat. Marine Chemistry, 73 , 97-112. https://doi.org/10.1016/S0304-4203(00)00099-2

Thiel, V., Peckmann, J., Seifert, R., Wehrung, P., Reitner, J., \& Michaelis, W. (1999). Highly isotopically depleted isoprenoids: Molecular markers for ancient methane venting. Geochimica et Cosmochimica Acta, 63, 3959-3966. https://doi.org/10.1016/S0016-7037(99)00177-5

Thierens, M., Browning, E., Pirlet, H., Loutre, M. F., Dorschel, B., Huvenne, V. A. I., ... Wheeler, A. J. (2013). Cold-water coral carbonate mounds as unique palaeo-archives: The Plio-Pleistocene Challenger Mound record (NE Atlantic). Quaternary Science Reviews, 73, 14-30. https:// doi.org/10.1016/j.quascirev.2013.05.006

Thierens, M., Titschack, J., Dorschel, B., Huvenne, V. A. I., Wheeler, A. J., Stuut, J. B., \& O'Donnell, R. (2010). The 2.6 Ma depositional sequence from the Challenger cold-water coral carbonate mound (IODP Exp. 307): Sediment contributors and hydrodynamic palaeo-environments. Marine Geology, 271, 260-277. https://doi.org/10.1016/j. margeo.2010.02.021

Timmers, P., Widjaja-Greefkes, H. C., Ramiro-Garcia, J., Plugge, C., \& Stams, A. (2015). Growth and activity of ANME clades with different sulfate and sulfide concentrations in the presence of methane. Frontiers in Microbiology, 6, https://doi.org/10.3389/ fmicb.2015.00988

Titschack, J., Goetz-Neunhoeffer, F., \& Neubauer, J. (2011). Magnesium quantification in calcites $\left[(\mathrm{Ca}, \mathrm{Mg}) \mathrm{CO}_{3}\right]$ by Rietveld-based XRD analysis: Revisiting a well-established method. American Mineralogist, 96, 1028-1038. https://doi.org/10.2138/am.2011.3665 
Valentine, D. L., \& Reeburgh, W. S. (2000). New perspectives on anaerobic methane oxidation. Environmental Microbiology, 2, 477-484. https ://doi.org/10.1046/j.1462-2920.2000.00135.x

Van der Land, C., Mienis, F., De Haas, H., Frank, N., Swennen, R., \& Van Weering, T. C. E. (2010). Diagenetic processes in carbonate mound sediments at the south-west Rockall Trough margin. Sedimentology, 57, 912-931. https://doi.org/10.1111/j.1365-3091.2009.01125.x

Van Rensbergen, P., Depreiter, D., Pannemans, B., \& Henriet, J. P. (2005). Seafloor expression of sediment extrusion and intrusion at the El Arraiche mud volcano field, Gulf of Cadiz. Journal of Geophysical Research: Earth Surface, 110. https://doi.org/10.1029/2004JF000165

Van Rensbergen, P., Depreiter, D., Pannemans, B., Moerkerke, G., Van Rooij, D., Marsset, B., ... Henriet, J.-P. (2005). The El Arraiche mud volcano field at the Moroccan Atlantic slope, Gulf of Cadiz. Marine Geology, 219, 1-17. https://doi.org/10.1016/j.margeo.2005.04.007

Van Rooij, D., Blamart, D., De Mol, L., Mienis, F., Pirlet, H., Wehrmann, L. M., ... Henriet, J. P. (2011). Cold-water coral mounds on the Pen Duick Escarpment, Gulf of Cadiz: The MiCROSYSTEMS project approach. Marine Geology, 282, 102-117. https://doi.org/10.1016/j. margeo.2010.08.012

Van Weering, T. C. E., de Haas, H., de Stigter, H. C., Lykke-Andersen, H., \& Kouvaev, I. (2003). Structure and development of giant carbonate mounds at the SW and SE Rockall Trough margins, NE Atlantic Ocean. Marine Geology, 198, 67-81. https://doi.org/10.1016/ S0025-3227(03)00095-1

Vanneste, H., Kastner, M., James, R. H., Connelly, D. P., Fisher, R. E., KellyGerreyn, B. A., ... Mills, R. A. (2012). Authigenic carbonates from the Darwin Mud Volcano, Gulf of Cadiz: A record of palaeo-seepage of hydrocarbon bearing fluids. Chemical Geology, 300, 24-39. https:// doi.org/10.1016/j.chemgeo.2012.01.006

Vinçon-Laugier, A., Grossi, V., Pacton, M., Escarguel, G., \& Cravo-Laureau, C. (2016). The alkyl glycerol ether lipid composition of heterotrophic sulfate reducing bacteria strongly depends on growth substrate. Organic Geochemistry, 98, 141-154. https://doi.org/10.1016/j.orgge ochem.2016.05.015

Wakeham, S. G., Lewis, C. M., Hopmans, E. C., Schouten, S., \& Sinninghe Damsté, J. S. (2003). Archaea mediate anaerobic oxidation of methane in deep euxinic waters of the Black Sea. Geochimica et Cosmochimica Acta, 67, 1359-1374. https://doi.org/10.1016/ S0016-7037(02)01220-6

Wefing, A.-M., Arps, J., Blaser, P., Wienberg, C., Hebbeln, D., \& Frank, N. (2017). High precision U-series dating of scleractinian cold-water corals using an automated chromatographic $\mathrm{U}$ and Th extraction. Chemical Geology, 475, 140-148. https://doi.org/10.1016/j.chemg eo.2017.10.036
Wehrmann, L. M., Templer, S. P., Brunner, B., Bernasconi, S. M., Maignien, L., \& Ferdelman, T. G. (2011). The imprint of methane seepage on the geochemical record and early diagenetic processes in cold-water coral mounds on Pen Duick Escarpment, Gulf of Cadiz. Marine Geology, 282, 118-137. https://doi.org/10.1016/j.margeo.2010.08.005

Wehrmann, L. M., Titschack, J., Böttcher, M. E., \& Ferdelman, T. G. (2015). Linking sedimentary sulfur and iron biogeochemistry to growth patterns of a cold-water coral mound in the Porcupine Basin, S.W. Ireland (IODP Expedition 307). Geobiology, 13, 424-442. https://doi.org/10.1111/gbi.12147

Weijers, J. W., Steinmann, P., Hopmans, E. C., Schouten, S., \& Sinninghe Damsté, J. S. (2011). Bacterial tetraether membrane lipids in peat and coal: Testing the MBT-CBT temperature proxy for climate reconstruction. Organic Geochemistry, 42, 477-486. https://doi. org/10.1016/j.orggeochem.2011.03.013

Wheeler, A. J., Beyer, A., Freiwald, A., de Haas, H., Huvenne, V. A. I., Kozachenko, M., ... Opderbecke, J. (2007). Morphology and environment of cold-water coral carbonate mounds on the NW European margin. International Journal of Earth Sciences, 96, 37-56. https://doi. org/10.1007/s00531-006-0130-6

Wienberg, C., Frank, N., Mertens, K. N., Stuut, J.-B., Marchant, M., Fietzke, J., ... Hebbeln, D. (2010). Glacial cold-water coral growth in the Gulf of Cádiz: Implications of increased palaeo-productivity. Earth and Planetary Science Letters, 298, 405-416. https://doi. org/10.1016/j.epsl.2010.08.017

Wienberg, C., Hebbeln, D., Fink, H. G., Mienis, F., Dorschel, B., Vertino, A., ... Freiwald, A. (2009). Scleractinian cold-water corals in the Gulf of Cádiz-First clues about their spatial and temporal distribution. Deep Sea Research Part I: Oceanographic Research Papers, 56, 18731893. https://doi.org/10.1016/j.dsr.2009.05.016

\section{SUPPORTING INFORMATION}

Additional supporting information may be found online in the Supporting Information section.

How to cite this article: Feenstra EJ, Birgel D, Heindel K, et al. Constraining the formation of authigenic carbonates in a seepage-affected cold-water coral mound by lipid biomarkers. Geobiology. 2020;18:185-206. https://doi. org/10.1111/gbi.12373 